\title{
Mapping autoantigen epitopes: molecular insights into autoantibody-associated disorders of the nervous system
}

\author{
Nese Sinmaz ${ }^{1}$, Tina Nguyen ${ }^{1}$, Fiona Tea ${ }^{1}$, Russell C. Dale ${ }^{1,2}$ and Fabienne Brilot ${ }^{1,2^{*}}$ (1)
}

\begin{abstract}
Background: Our knowledge of autoantibody-associated diseases of the central (CNS) and peripheral (PNS) nervous systems has expanded greatly over the recent years. A number of extracellular and intracellular autoantigens have been identified, and there is no doubt that this field will continue to expand as more autoantigens are discovered as a result of improved clinical awareness and methodological practice. In recent years, interest has shifted to uncover the target epitopes of these autoantibodies.

Main body: The purpose of this review is to discuss the mapping of the epitope targets of autoantibodies in CNS and PNS antibody-mediated disorders, such as N-methyl-D-aspartate receptor (NMDAR), a-amino-3-hydroxy-5-methyl-4isoxazolepropionic acid receptor (AMPAR), leucine-rich glioma-inactivated protein 1 (Lgi1), contactin-associated proteinlike 2 (Caspr2), myelin oligodendrocyte glycoprotein (MOG), aquaporin-4 (AQP4), 65 kDa glutamic acid decarboxylase (GAD65), acetylcholine receptor (AChR), muscle-specific kinase (MuSK), voltage-gated calcium channel (VGCC), neurofascin (NF), and contactin. We also address the methods used to analyze these epitopes, the relevance of their determination, and how this knowledge can inform studies on autoantibody pathogenicity. Furthermore, we discuss triggers of autoimmunity, such as molecular mimicry, ectopic antigen expression, epitope spreading, and potential mechanisms for the rising number of double autoantibody-positive patients.
\end{abstract}

Conclusions: Molecular insights into specificity and role of autoantibodies will likely improve diagnosis and treatment of CNS and PNS neuroimmune diseases.

Keywords: CNS disorders, PNS disorders, Autoantibody, Epitope mapping, Epitope spreading

Abbreviations: Aa, Amino acids; AChR, Acetylcholine receptor; ADEM, Acute disseminated encephalomyelitis; ADS, Acquired demyelinating syndromes; AIPD, Acute inflammatory demyelinating polyradiculoneuropathy; AMAN, Acute motor axonal neuropathy; AMPAR, a-Amino-3-hydroxy-5-methyl-4-isoxazolepropionic acid receptor; AQP4, Aquaporin-4; ATD, Amino-terminal domains; BON, Bilateral optic neuritis; Caspr2, Contactin-associated proteinlike 2; CIDP, Chronic inflammatory demyelinating polyneuropathy; CL, Catalytic loop; CNS, Central nervous system; CRION, Chronic relapsing inflammatory optic neuropathy; CSF, Cerebrospinal fluid; CTD, C-terminal domain; D2R, Dopamine-2 receptor; Disc, Discoidin; DNA, Deoxyribonucleic acid; DPPX, Dipeptidyl-peptidase-like protein-6; EAE, Experimental autoimmune encephalomyelitis; EAMG, Experimental autoimmune myasthenia gravis; ELISA, Enzyme-linked immunosorbent assay; FibC, FibrinogenC; Fz, Frizzled; GABA $R$, $\gamma$-Aminobutyric acid receptor-A; $\mathrm{GABA}_{B} \mathrm{R}$, $\mathrm{Y}$-Aminobutyric acid receptor-B; GAD65, 65-kDa glutamic acid decarboxylase; GBS, Guillain-Barre syndrome; (Continued on next page)

\footnotetext{
* Correspondence: fabienne.brilot@sydney.edu.au

'Brain Autoimmunity Group, Institute for Neuroscience and Muscle Research,

The Kids Research Institute at the Children's Hospital at Westmead, University

of Sydney, Locked Bag 4001, Westmead, NSW 2145, Australia

${ }^{2}$ Discipline of Child and Adolescent Health, Sydney Medical School,

University of Sydney, Sydney, Australia
}

(c) 2016 The Author(s). Open Access This article is distributed under the terms of the Creative Commons Attribution 4.0 International License (http://creativecommons.org/licenses/by/4.0/), which permits unrestricted use, distribution, and reproduction in any medium, provided you give appropriate credit to the original author(s) and the source, provide a link to the Creative Commons license, and indicate if changes were made. The Creative Commons Public Domain Dedication waiver (http://creativecommons.org/publicdomain/zero/1.0/) applies to the data made available in this article, unless otherwise stated. 


\begin{abstract}
(Continued from previous page)
GlyR, Glycine receptor; HEK293, Human embryonic kidney 293 cells; HSV, Herpes simplex virus; HSVE, Herpes simplex virus encephalitis; ICC, Immunocytochemistry; Ig, Immunoglobulin; Lam, LamininG; LEMS, Lambert-Eaton myasthenic syndrome; Lgi1, Leucine-rich glioma-inactivated protein 1; Lrp4, Lipoprotein receptor-related protein 4; MBP, Myelin basic protein; mEPSCs, Miniature excitatory postsynaptic current; MG, Myasthenia gravis; mGluR5, Metabotropic glutamate receptor 5; mMOG, Mouse myelin oligodendrocyte glycoprotein; MOG, Myelin oligodendrocyte glycoprotein; MS, Multiple sclerosis; MuSK, Muscle-specific kinase; NF, Neurofascin; NMDAR, N-methyl-D-aspartate receptor; NMJ, Autoimmune neuromuscular junction; NMO, Neuromyelitis optica; NMOSD, Neuromyelitis optica spectrum disorder; NMT, Acquired neuromyotonia; NPSLE, Neuropsychiatric systematic lupus erythematosus; NTD, Nterminal domain; OAPS, Orthogonal arrays of particles; PLP, Pyridoxal 5'-phosphate; PNGase F, Peptide-N-Glycosidase F; PNS, Peripheral nervous system; rAb, Recombinant antibody; SLE, Systematic lupus erythematosus; SOX1, Sex determining region Y-box 1; SPS, Stiff person syndrome; TM, Transmembrane; TMEV-IDD, Theiler's murine encephalomyelitis virus-induced demyelinating disease; TPO, Thyroid peroxidase; VGCC, Voltage-gated calcium channel; VGKC, Voltage-gated potassium channel.
\end{abstract}

\section{Background}

Autoantibodies can be associated with diseases that affect the central nervous system (CNS) or peripheral nervous system (PNS). The associated autoantibodies can be directed against intracellular or extracellular autoantigens [1-3], and the clinical phenotype of patients is diverse, encompassing movement disorders and neuropsychiatric disorders [4, 5]. Antibodies targeting intracellular antigens are not considered pathogenic but are sometimes believed to be biomarkers of an underlying tumor [6]. Conversely, antibodies targeting extracellular domains of neuronal cell surface receptors or synaptic proteins, sometimes associated with a tumor, are generally considered to be pathogenic and can modulate receptor function or decrease receptor density at the cell surface [7-9]. Autoantigens found in CNS antibodymediated disorders include $N$-methyl-D-aspartate receptor (NMDAR) [10], $\alpha$-amino-3-hydroxy-5-methyl-4-isoxazolepropionic acid receptor (AMPAR) [11], glycine receptor (GlyR) [12], components of the voltage-gated potassium channel (VGKC) complex, including leucine-rich gliomainactivated protein 1 (Lgi1) and contactin-associated protein-like 2 (Caspr2) [13-15], $\gamma$-aminobutyric acid receptor-B $\left(G_{A B A} R\right)$ [16], $\gamma$-aminobutyric acid receptorA $\left(\mathrm{GABA}_{\mathrm{A}} \mathrm{R}\right)$ [17], metabotropic glutamate receptor 5 (mGluR5) [18], dipeptidyl-peptidase-like protein-6 (DPPX) [19], dopamine-2 receptor (D2R) [20], myelin oligodendrocyte glycoprotein (MOG) [21-23], aquaporin-4 (AQP4) [24], $65 \mathrm{kDa}$ glutamic acid decarboxylase (GAD65) [25], neurofascin (NF) [26], and contactin [27]. Furthermore, a number of different autoantigens have been discovered in neuromuscular junction antibodymediated disorders. These include acetylcholine receptor (AChR) [28], muscle-specific kinase (MuSK) [29], lipoprotein receptor-related protein 4 (Lrp4) [30], all associated with myasthenia gravis (MG), and voltage-gated calcium channel (VGCC) associated with PNS Lambert-Eaton myasthenic syndrome (LEMS) [31].
The discovery of antibody-associated brain disorders has helped to identify patients amenable to immunotherapies, leading to more rapid recovery and improved patient outcome. Recently, research has focused on the discovery of autoantibody epitope(s) to understand the mechanism of autoantibody pathogenicity. Herein, we review reported target epitope(s) for known antibodymediated disorders of the nervous system, address the relevance of these studies, explore the notion of epitope spreading, and discuss the issue of double autoantibodypositive patients.

\section{Epitope mapping of antibody-mediated brain disorders}

Methods to map autoantibody epitopes

An important factor to consider in the identification of autoantigens and their epitope targets is the methodology that is used in the experimental setting. Current practices include subcloning and mutating the antigen of interest, either by deleting entire regions or making point mutations. Autoantibody epitope specificity is usually investigated using a cell-based assay followed by fluorescent microscopy or flow cytometry analysis [9]. However, western blots [32], radioimmunoassays [33], and ELISAs [34] have also been used to determine antigenic epitopes. Fundamentally, pathogenic autoantibodies recognize cell surface antigens in their native conformation. As such, it is important to remember that the type of method utilized will therefore determine whether the antigenic epitope remains in its native three-dimensional conformation or is converted to a denatured or linear configuration. Indeed, the use of a live cell-based assay, ELISA, or western blot will influence protein conformation, and hence results, interpretation, and conclusions. Furthermore, the live or fixed/permeabilized status of cells used in cell-based assays is critical as the latter also affects conformation and has led to high prevalence of autoantibodies in 
healthy donors (recently reviewed in [9]). An overview of the methodology used in mapping the epitopes is given in Table 1.

\section{Autoimmune encephalitis}

Anti-NMDAR encephalitis is the most commonly recognized autoimmune encephalitis (reviewed in [1]). It is associated with anti-NMDAR antibodies, has been reported in females and males, and has been observed in all age groups, from young children to the elderly [13]. Due to the severity of anti-NMDAR encephalitis, as well as its rising prevalence, several studies have strived to uncover the target epitope of anti-NMDAR antibodies and also to explore the mechanisms of antiNMDAR antibody pathogenicity. NMDARs are composed of two GluN1 (also called NR1) and two GluN2/ 3 (also called NR2 and NR3) subunits that form a central ion channel (Fig. 1). Importance of the conservation of conformational antigen has been shown by the lack of immunoreactivity of anti-NMDAR antibody on immunoblots [10]. In 2012, the epitope of antiNMDAR antibodies was mapped using a series of NMDAR mutants expressed in human embryonic kidney (HEK) 293 cells that were incubated with CSF from patients with and without anti-NMDAR encephalitis [35]. The first step was to distinguish which subunit was involved in antibody binding. Anti-NMDAR antibody-positive CSF did not recognize the GluN2 variant of NMDAR by immunocytochemistry, but they did recognize GluN1 subunit and a splice variant of GluN1 [35]. GluN subunits are made up of two extracellular domains; the amino (N)-terminal domain (ATD) and the ligand-binding domain (LBD) consisting of segment 1 (S1) and segment 2 (S2), followed by three transmembrane-spanning domains (TM1, 3, 4), a transmembrane loop (TM2), and an intracellular carboxyl (C)-terminal domain (Fig. 1a). To determine whether it was the extracellular ATD or S1/S2 domains that were important for antibody binding, two different constructs were created. The first mutant included only the ATD domain and missed the S1/S2 domains, which resulted in intense patient antibody staining. The second construct excluded ATD and contained S1/S2 only, which abolished antibody binding [35]. These results suggested that the ATD of GluN1 is necessary for antibody recognition. Additional deletion constructs were created, including single-point mutations within the ATD, to define specific antibody binding. Among these, the most important mutant was N368D/G369I double mutant, which prevented patient antibodies from binding. Therefore, residues N368/ G369 were found to be important targets of anti-NMDAR antibodies. As expected, control patients without antiNMDAR antibodies did not stain for NMDAR mutants.
Interestingly, the ATD of NMDAR includes seven putative N-linked glycosylation sites, one of which found at position N368. Analysis of N368Q mutant with patient samples showed reduced immunoreactivity but did not abolish antibody binding to the same extent as the double mutation of N368/G369 [35]. This result is interesting because it suggests that $\mathrm{N}$-glycosylation sites are involved in creating the ideal epitope conformation. Pathogenic studies, discussed below, have also been carried out using this mutant.

Anti-AMPAR antibodies are detected in patients with anti-AMPAR encephalitis in a small number of described cases [11, 36]. AMPAR is an ionotropic glutamate receptor comprising of four subunits, GluR1-4 (Fig. 1). The extracellular domain contains ATD, LBD, three transmembrane domains, a transmembrane loop, and a C-terminal cytoplasmic tail. In 2014, the epitope of AMPAR was mapped [32] (Fig. 1c). Two different methods were employed to test antibody specificity in patient serum and CSF: immunocytochemistry following expression of mutated AMPAR in HEK293 cells and western blots using mutant AMPAR fused to thioredoxin tag expressed in bacteria. Anti-AMPAR antibodies were found to react to both GluR1 and GluR2 subunits of AMPAR. Deletion of S1 domain resulted in little to no immunoreactivity, and mutants lacking the bottom lobe of ATD prevented antibody binding. These results indicate that the main immunogenic targets of antiAMPAR antibodies are located within the bottom lobe of ATD, but the precise residues were not mapped (Fig. 1c). In the case of AMPAR, although its tertiary structure is similar to the one of NMDAR and the AMPAR epitopes were located within the same glycosylation-prone region, the influence of glycosylation was not demonstrated. Anti-AMPAR antibodies have also been shown to influence receptor function (please see below for pathogenicity).

Anti-Caspr2 antibody epitope was mapped in 2015 $[37,38]$. Caspr2 is an axonal protein located at the juxtaparanodes of myelinated axons and, along with Lgi1, is part of the VGKC complex. Caspr2 is made up of eight distinctive subdomains. From the $\mathrm{N}$ - terminus, these include the following: discoidin (Disc), lamininG (Lam1), lamininG (Lam2), epidermal growth factor 1 (Egf1), fibrinogenC (FibC), lamininG (Lam3), Egf (Egf2), and lamininG (Lam4) (Fig. 1d). The specificity of anti-Caspr2 antibody was also investigated using a series of deletion constructs, and then antibody-positive patient sera were tested by cellbased assay followed by immunocytochemistry [37] or flow cytometry [38]. A variety of different constructs were created involving single and multiple domain deletions to uncover the subdomain(s) involved in antibody binding. Autoantibody immunoreactivity was found to be specific to the extracellular N-terminal domain of Caspr2 and 
Table 1 Epitope target(s) of CNS and PNS human autoantibodies

\begin{tabular}{|c|c|c|c|c|c|c|c|c|c|}
\hline & CNS/PNS disorder & Antigen & $\begin{array}{l}\text { Target: extra/ } \\
\text { intra }\end{array}$ & Main epitope & Other epitopes & $\begin{array}{l}\text { Number of } \mathrm{N}- \\
\text { glycosylation sites }\end{array}$ & $\begin{array}{l}\text { Sample } \\
\text { type }\end{array}$ & Methodology & Reference \\
\hline \multirow[t]{11}{*}{$\overline{C N S}$} & $\begin{array}{l}\text { Anti-NMDAR } \\
\text { encephalitis }\end{array}$ & Neuronal NMDAR & Extra & $\begin{array}{l}\text { GluN1/NR1 subunit } \\
\text { (ATD, N368/G369) }\end{array}$ & - & $10\left(\mathrm{~N} 368^{\mathrm{a}}\right)$ & CSF & Subcloning/ICC & Gleichman et al. [35] \\
\hline & SLE & & Extra & $\begin{array}{l}\text { NR2A/2B subunit } \\
(\mathrm{LBD} / \mathrm{S} 1 \text {, aa283-287) }\end{array}$ & & 6 & Sera/CSF & $\begin{array}{l}\text { Phage display peptide } \\
\text { library }\end{array}$ & DeGiorgio et al. [67]. \\
\hline & $\begin{array}{l}\text { Anti-AMPAR } \\
\text { encephalitis }\end{array}$ & Neuronal AMPAR & Extra & $\begin{array}{l}\text { GluR1 subunit } \\
\text { (Bottom of ATD) }\end{array}$ & S1 domain & 6 & Sera/CSF & $\begin{array}{l}\text { Subcloning/ICC, Fusion } \\
\text { protein-based western } \\
\text { blot }\end{array}$ & Gleichman et al. [32] \\
\hline & \multirow[t]{2}{*}{$\begin{array}{l}\text { Autoimmune } \\
\text { encephalitis }\end{array}$} & Neuronal Caspr2 & Extra & Disc domain & $\begin{array}{l}\text { Lam1, Lam2, Egf1 } \\
\text { domains }\end{array}$ & 12 & Sera & $\begin{array}{l}\text { Subcloning/ICC, western } \\
\text { blot }\end{array}$ & Olsen et al. [37] \\
\hline & & & Extra & Disc, Lam1 domains & - & & Sera/CSF & $\begin{array}{l}\text { Flow cytometry cell- } \\
\text { based assay }\end{array}$ & Pinatel et al. [38] \\
\hline & \multirow[t]{2}{*}{ Encephalitis/SPS } & Neuronal GAD65 & Intra & $\begin{array}{l}\text { Catalytic region } \\
\text { (aa221-444) }\end{array}$ & C-terminal domain & 0 & Sera & $\begin{array}{l}\text { Immunoprecipitation } \\
\text { assay }\end{array}$ & Fouka et al. [48] \\
\hline & & & Intra & $\begin{array}{l}\text { aa4-22, aa308-365, } \\
\text { aa451-585 }\end{array}$ & - & & Sera & Competition assay & Raju et al. [47] \\
\hline & $\begin{array}{l}\text { NMOSD/BON/ } \\
\text { ADEM/CRION }\end{array}$ & $\begin{array}{l}\text { Oligodendrocytes - } \\
\text { MOG }\end{array}$ & Extra & $\begin{array}{l}\beta \text { strand/CC'-loop } \\
(\mathrm{P} 42)\end{array}$ & FG-loop (H103/S104) & $1\left(\mathrm{~N} 60^{\mathrm{a}}\right)$ & Sera & $\begin{array}{l}\text { Subcloning/cell-bound } \\
\text { reactivity assay }\end{array}$ & Mayer et al. [56] \\
\hline & \multirow[t]{3}{*}{ NMO } & $\begin{array}{l}\text { Astrocytes - AQP4 } \\
\text { isoform M } 23\end{array}$ & Extra & Loop A (aa61-64) & $\begin{array}{l}\text { Loop C (aa146-150) } \\
\text { Loop E (W227) }\end{array}$ & 2 & Sera & Subcloning/ICC & Pisani et al. [62] \\
\hline & & & Intra & $\begin{array}{l}\text { aa1-22, Loop B (aa88- } \\
\text { 113), aa252-275 }\end{array}$ & - & & Sera & ELISA & Kampylafka et al. [61] \\
\hline & & & Extra & Loop A (aa66-69) & $\begin{array}{l}\text { Loop C (N153), Loop E } \\
(\mathrm{H} 230)\end{array}$ & & Sera/CSF & Cell-based assay & Tuller et al. [65] \\
\hline \multirow[t]{8}{*}{ PNS } & \multirow[t]{4}{*}{ MG } & Muscle - AChR & Extra & a1 subunit (aa67-76) & - & 1 & Sera & $\begin{array}{l}\text { Solid-phase } \\
\text { radioimmunoassay }\end{array}$ & Tzartos et al. [33] \\
\hline & & & Extra & $\begin{array}{l}\text { a1 subunit (aa1-14, } \\
\text { aa67-76) }\end{array}$ & - & & Sera & Radioimmunoassay & Luo et al. [79] \\
\hline & & & Extra & $\begin{array}{l}\text { a1 subunit (N68, } \\
\text { D71) }\end{array}$ & - & & Sera & $\begin{array}{l}\text { Peptide competition } \\
\text { binding assay }\end{array}$ & $\begin{array}{l}\text { Papadouli et al. [80] } \\
\text { Wahlsten et al. [81] }\end{array}$ \\
\hline & & & Intra & - & $\begin{array}{l}\text { a1 subunit (aa373-380), } \\
\text { ß1 subunit (aa354-359) }\end{array}$ & & Sera & Competition assay & Tzartos et al. [82] \\
\hline & \multirow[t]{4}{*}{ MG } & Muscle-MuSK & Extra & Ig-like domain 1 & $\begin{array}{l}\text { Ig-like domain 2, Ig-like } \\
\text { domain 3/ Fz-like domain }\end{array}$ & 2 & Sera & $\begin{array}{l}\text { Radioimmunoprecipitation } \\
\text { assay }\end{array}$ & McConville et al. [84] \\
\hline & & & Extra & $\begin{array}{l}\text { Ig-like domain 1, } \\
\text { Ig-like } \\
\text { domain } 2\end{array}$ & - & & Sera & $\begin{array}{l}\text { Radioimmunoprecipitation } \\
\text { assay }\end{array}$ & Ohta et al. [85] \\
\hline & & & Extra & Ig-like domain 1 & Ig-like domain 2 & & Sera & $\begin{array}{l}\text { Competition binding, } \\
\text { ELISA, subcloning/ICC }\end{array}$ & Huijbers et al. [83] \\
\hline & & & Extra & lg-like domain 1 & & & Sera & ELISA & Huijbers et al. [34] \\
\hline
\end{tabular}


Table 1 Epitope target(s) of CNS and PNS human autoantibodies (Continued)

\begin{tabular}{|c|c|c|c|c|c|c|c|c|}
\hline & & & & $\begin{array}{l}\text { Ig-like domain 2, } \\
\text { Fz-like domain }\end{array}$ & & & & \\
\hline$M G$ & Titin & Intra & $\begin{array}{l}\text { Ig C2-like domain, } \\
\text { Fn-like domain } \\
\text { (MGT30) }\end{array}$ & - & 0 & Sera & $\begin{array}{l}\text { CDNA expression } \\
\text { library }\end{array}$ & Gautel et al. [88] \\
\hline \multirow[t]{3}{*}{ LEMS } & \multirow[t]{3}{*}{$\begin{array}{l}\text { Neuronal } \\
\text { P/Q-type VGCC }\end{array}$} & Extra & $\begin{array}{l}\text { a1 subunit (linker } \\
\text { region of S5-6 in } \\
\text { repeated domains } \\
\text { II, III, IV) }\end{array}$ & $\beta 1$ subunit & 1 & Sera & $\begin{array}{l}\text { Radioimmunoprecipitation } \\
\text { assay }\end{array}$ & Parsons et al. [94] \\
\hline & & Extra & $\begin{array}{l}\text { a1 subunit (linker } \\
\text { region of domain IV) }\end{array}$ & $\begin{array}{l}\text { a1 subunit (linker } \\
\text { region of domain II) }\end{array}$ & & Sera & $\begin{array}{l}\text { Immunoprecipitation } \\
\text { assay }\end{array}$ & Takamori et al. [95] \\
\hline & & Extra & $\begin{array}{l}\text { a1 subunit (linker } \\
\text { region of domain III) }\end{array}$ & - & & Sera & Immunoblot & Iwasa et al. [96] \\
\hline \multirow[t]{2}{*}{ NMT } & \multirow[t]{2}{*}{ Neuronal Caspr2 } & Extra & Disc domain & Lam1, Lam2, Egf1 & 12 & Sera & $\begin{array}{l}\text { Subcloning/ICC, } \\
\text { Western blot }\end{array}$ & Olsen et al. [37] \\
\hline & & Extra & Disc, Lam1 domains & - & & Sera/CSF & $\begin{array}{l}\text { Flow cytometry } \\
\text { cell-based assay }\end{array}$ & Pinatel et al. [38] \\
\hline NPSLE & Neuronal NMDAR & Extra & $\begin{array}{l}\text { GluN1/NR1 (aa19-44, } \\
\text { aa56-81) }\end{array}$ & - & 10 & Sera/CSF & ELISA & Ogawa et al. [72] \\
\hline \multirow[t]{2}{*}{$\begin{array}{l}\text { CIDP, GBS, } \\
\text { AMAN, AIPD }\end{array}$} & Neuronal NF186 & Extra & $\begin{array}{l}\text { Fn } \vee \text { domain, Mucin- } \\
\text { like domain }\end{array}$ & \multirow[t]{2}{*}{ - } & \multirow[t]{2}{*}{8} & \multirow[t]{2}{*}{ Sera } & \multirow[t]{2}{*}{ Cell-based assay } & \multirow[t]{2}{*}{ Ng et al. [107] } \\
\hline & Glial NF155 & Extra & $\begin{array}{l}\text { Fn III domain, Fn IV } \\
\text { domain }\end{array}$ & & & & & \\
\hline CIDP, GBS & Neuronal Contactin & Extra & lg C2-like domain $V^{b}$ & - & 9 & Sera & Subcloning/ICC & Labasque et al. [108] \\
\hline $\begin{array}{l}\text { AChR acetylcholine re } \\
\text { acute disseminated e } \\
\text { CRION chronic relapsi } \\
\text { decarboxylase, GBS G } \\
\text { Syndrome, Lgil leucir } \\
\text { aspartate receptor, N/ } \\
\text { SPS Stiff Person Synd } \\
\text { a Potentially importan } \\
\text { b } \mathrm{N} \text {-qlycosylation sites }\end{array}$ & $\begin{array}{l}P D \text { acute inflammator } \\
\text { nyelitis, } A Q P 4 \text { aquapo } \\
\text { matory optic neuropat } \\
\text { re syndrome, ICC imm } \\
\text { oma-inactivated prote } \\
\text { myelitis optica, NMOSL } \\
\text { type } 1 \text { Diabetes, VGC } \\
\text { tion site involved in a } \\
73 / \mathrm{N} 494 \text { involved in a }\end{array}$ & $\begin{array}{l}1 G \text { my } \\
\text { romye } \\
\text { age-gi } \\
\text { dy bin } \\
\text { yy bin }\end{array}$ & $\begin{array}{l}\text { adiculoneuropathy, } A M A \\
\text { tic neuritis, Caspr2 conta } \\
\text { fluid, } D N A \text { deoxyribonu } \\
\text { immunoglobulin, } L B D \text { lic } \\
\text { ravis, } M O G \text { myelin oligo } \\
\text { syndrome disorder, } N M \\
\text { m channel, } V G K C \text { voltag } \\
\text { formation of epitope }\end{array}$ & $\begin{array}{l}\text { nd binding domain, } L \\
\text { androcyte glycoprote } \\
\text { acquired neuromyot } \\
\text { gated potassium cha }\end{array}$ & ot ap & $\begin{array}{l}\text { 3-hydroxy-5- } \\
\text { tory demye } \\
\text { 1, Fn fibrone } \\
\text { ic } \\
\text { \& muscle-spe } \\
\text { ystematic lu }\end{array}$ & $\begin{array}{l}\text {-methyl-4-isoxazolepropionic ac } \\
\text { elinating polyneuropathy, CNS } \\
\text { ectin-type III, Fz Frizzled, GAD65 } \\
\text { eecific kinase, NF neurofascin, NN } \\
\text { lupus erythematosus, PNS periph }\end{array}$ & $\begin{array}{l}\text { cid receptor, } A D E M \\
\text { central nervous system, } \\
565 \mathrm{kDa} \text { glutamic acid } \\
\text { MDAR N-methyl-D- } \\
\text { heral nervous system, }\end{array}$ \\
\hline
\end{tabular}




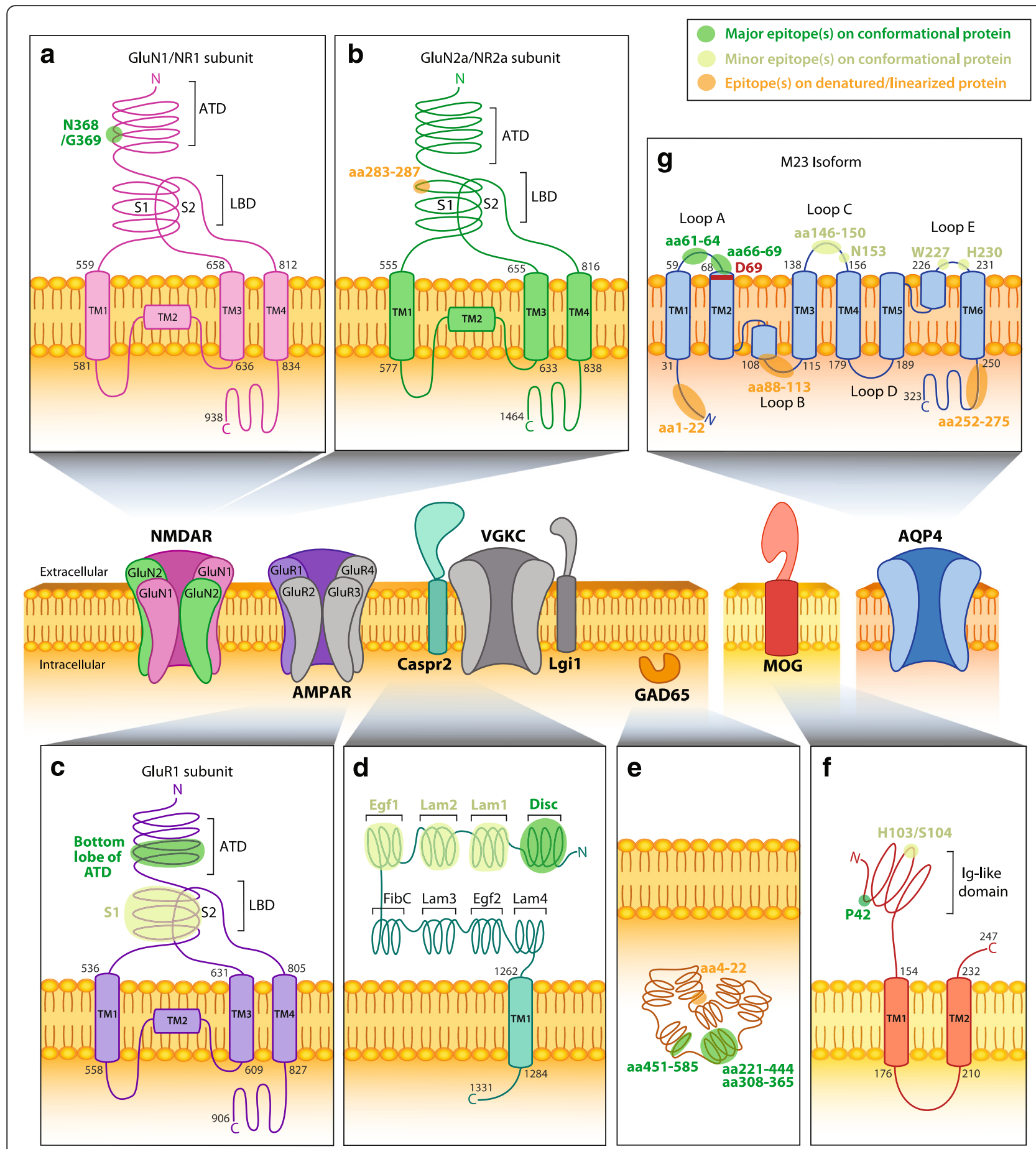

Fig. 1 (See legend on next page.) 
(See figure on previous page.)

Fig. 1 Epitopes of human CNS autoantibodies. Two subtypes of ionotropic glutamate receptors (iGluRs) are the N-methyl-D-aspartate receptor (NMDAR) and the a-amino-3-hydroxy-5-methyl-4-isoxazolepropionic acid receptor (AMPAR). Subunits of NMDAR (a, b) and AMPAR (c) contain an extracellular amino terminal domain (ATD) and a ligand-binding domain (LBD) formed by segment 1 (S1) and segment 2 (S2). Anti-NMDAR antibodies recognize amino acid (aa) N368 and G369 which reside on the bottom lobe in the ATD of the GluN1 subunit (a, Q05586) [35]. Anti-NMDAR antibodies also bind to an epitope at aa283-287 within S1 of the LBD in subunits GluN2a and GluN2b (b, Q12879; only GluN2A is shown) [67]. AntiAMPAR antibodies are directed against an extracellular epitope within the bottom lobe in the ATD of the GluR1 subunit (c, P42261), but specific aa in the ATD have not been mapped [32]. d Contactin-associated protein 2 (Caspr2, Q9UHC6) consists of eight domains and forms part of the voltage-gated potassium channel (VGKC) complex with the leucine-rich glioma-inactivated protein 1 (Lgi1). Anti-Caspr2 antibodies recognize the extracellular N-terminal half (domains I-IV; discoidin (DisC), lamininG (Lam)-1, Lam2, and epidermal growth factor 1 (Egf1), respectively), but most commonly bind to an epitope within the Disc domain [37, 38]. e Anti-cytoplasmic enzyme glutamic acid decarboxylase 65 (GAD65) antibodies recognize an epitope at aa221-444 [48], aa451-585, and aa308-365 [47]. Anti-GAD65 antibodies have also been shown to bind to linearized protein at aa4-22 [47]. f Myelin oligodendrocyte glycoprotein (MOG, Q16653) is a myelin protein expressed on oligodendrocytes. Anti-MOG antibodies recognize a epitopes at P42 and at H103/S104 within the immunoglobulin (Ig)-like domain [56]. g Aquaporin-4 isoform M23 (AQP4-M23) is a water channel expressed on astrocytes. Anti-AQP4-M23 antibodies recognize epitopes within loop C (aa146-150) and loop E (aa227-228), but mostly in loop A (aa61-64) [62]. An additional study identified extracellular epitopes within loop A (aa66-69), loop C (N153), and loop E (H230) [65]. Reported intracellular epitopes include aa1-22, aa88-113, and aa252275 [61]. D69 (red) is vital in maintaining the conformational structure of loop A [63]. Human AQP4-M23 sequence is derived from [210, 211]. Human protein topology, i.e., aa sequences and transmembrane domains (TM), is adapted from UniProt database and UniProt identifiers are shown between brackets. Diagrams do not depict protein crystal structure. Green highlights indicate major (dark green) and minor (light green) epitopes mapped by methods which retain the native in vivo conformational structure of proteins, such as cell-based assays. Orange highlights epitopes determined by methods that denature or linearized proteins, such as western blots and ELISAs (Table 1)

that autoantibodies target multiple subdomains, with the Disc domain containing the major target epitope. Indeed, the $\Delta$ Disc single domain deletion construct was the only one that showed significantly reduced immunoreactivity, but without a complete abrogation of binding [37]. Therefore, Olsen et al. concluded that while a major epitope is contained within the Disc domain of Caspr2, additional unknown epitopes also exist $[37,38]$. The second study supports these conclusions [38] and also showed that N-terminal Disc and Lam1 domains are major antigenic targets in sera and CSF [38] (Fig. 1d). Furthermore, deglycosylation by tunicamycin or Peptide-N-Glycosidase F (PNGase F) did not prevent anti-Caspr2 antibody recognition, suggesting that $\mathrm{N}$-linked glycosylation sites on Caspr2 are not important for antibody binding [37].

Anti-GAD65 antibodies have been associated with various syndromes including encephalitis, stiff person syndrome (SPS), cerebellar ataxia, epilepsy, and type 1 diabetes [25, 39-42]. GAD65 belongs to the pyridoxal 5 '-phosphate (PLP)-dependent enzymes, involved in the synthesis of the neurotransmitter GABA [43, 44]. GAD65 consists of a PLP-binding domain, C-terminal domain (CTD), catalytic loop (CL), and N-terminal domain (NTD). In type 1 diabetes, the major target of antiGAD65 antibodies have been mapped to PLP- and Cterminal regions $[45,46]$. However, using competition binding with recombinant monoclonal antibodies, antiGAD65 antibodies from stiff person syndrome were found to recognize a linear epitope on residues 4-22 and two conformational epitopes spanning residues 308-365 and 451-585 in $\sim 30$ and $\sim 70 \%$ patients, respectively [47] (Fig. 1e). These antigenic targets were not recognized by serum antibodies from patients with type
1 diabetes [47]. This suggests that epitopes could be different between diseases. Furthermore, differences in autoantibody epitope may also explain variations between patient clinical phenotype even though they are all anti-GAD65 antibody-positive. A more recent study aimed to examine epitope specificity among all antiGAD65 antibody-positive patients with different neurological syndromes [48]. They found that patients predominantly recognized the middle domain, corresponding to the catalytic region of GAD65 (aa221-444) (Fig. 1e). Nand $\mathrm{C}$-terminals were also recognized, but to a lesser extent, and there was no GAD-specific epitope that defined any neurological disorder [48].

\section{Autoimmune demyelinating diseases}

Patients with demyelinating diseases, including acute disseminated encephalomyelitis (ADEM), neuromyelitis optica spectrum disorder (NMOSD), bilateral optic neuritis (BON), and chronic relapsing inflammatory optic neuropathy (CRION), have been found to be associated with antibodies against conformationally intact MOG [21, 49-55] (recently reviewed in [51]). MOG is a glycoprotein from the immunoglobulin superfamily, localized to the outermost layer of myelin (Fig. 1f), allowing easy access for potential pathogenic autoantibody binding. To gain precise insight into anti-MOG antibody recognition, 111 patient sera derived from MS, NMOSD, ADEM, or CRION patients were analyzed by live cellbased assay and flow cytometry after binding on MOG mutated by point mutagenesis within its extracellular immunoglobulin (Ig)-like domain [56]. Overall, seven epitopes were distinguished, and all were located within the $ß$ strands of MOG, with the most frequently recognized epitope positioned in the CC'-loop within the 
extracellular Ig-like domain. Interestingly, the major epitope was a proline at position 42 within the CC'-loop, and the second most commonly recognized epitope was at positions 103 and 104 within the FC'-loop (Fig. 1f). The epitope specificity was similar in all of the disorders analyzed. Interestingly, position 42 is occupied by a serine in mouse MOG (mMOG). Due to mutation at P42, patient sera that recognized human MOG did not recognize $\mathrm{mMOG}$, suggesting that the use of a mouse model to study anti-MOG antibody pathogenicity may be difficult due to failure of human autoantibody to recognize $\mathrm{mMOG}$.

Arguably, the most recognized autoantibodies in demyelination are anti-AQP4 antibodies that are associated with neuromyelitis optica (NMO), a severe demyelinating disorder affecting the optic nerve and spinal cord. Anti-AQP4 antibody-positive patients present with longitudinal extended transverse myelitis and recurrent optic neuritis $[57,58]$. Serum anti-AQP4 antibodies are polyclonal and have been shown to bind to conformational epitopes and linear peptides [59]. Epitope mapping has been complicated by the tendency of AQP4 to multimerize into membrane-bound homo- or heterotetramers and higher order structures called orthogonal arrays of particles (OAPs) [60]. A study screened for anti-peptide antibodies by ELISA and found that antiAQP4 antibody-positive sera were reactive against three different peptides of AQP4, including aa1-22 (42.9\% of patients), aa88-113 (33\%), and aa252-275 (23.8\%). All epitopes identified were found to localize to the intracellular domains of the isoform M23 of AQP4 (AQP4M23) [61] (Fig. 1g). However, when conformational APQ4-M23 was used, other epitopes were determined (Fig. 1g), and it is likely that these drive diseaserelevance and pathogenicity. Two main conformational epitopes were found in extracellular loop A (aa61-64) and loop C (aa146-150) [62] (Fig. 1g). Mutations at W227 in the third extracellular loop E also influenced autoantibody binding in experiments using double loop $\mathrm{A} / \mathrm{E}$ and $\mathrm{C} / \mathrm{E}$ mutants. The importance of the conformation was also confirmed by a further study in which a point deletion at D69 within the second transmembrane domain altered the structural rearrangement of extracellular loop A and impaired antibody binding in $85.7 \%$ of NMO patients [63]. These studies emphasize once again how the role of the conformation into epitope assembly can be teased out by the choice of methodology. Interestingly, another recent study focused on the epitope bound by recombinant anti-AQP4 antibodies (rAb) derived from CSF plasmablasts of NMO patients and had the added advantage of dealing with monoclonal rAb rather than patient polyclonal serum. They found that the amino acids within loop C (T137/P138, Val150, and N153) and loop E (H230/W231) were important for antibody binding (Fig. 1f), as well as an influence of loop A on rAb binding [64]. These epitopes are also bound by human serum autoantibodies as it has recently been confirmed by cell-based assay [65].

\section{Neuropsychiatric SLE}

Neuropsychiatric symptoms such as cognitive dysfunction, mood disorders, and/or psychosis develop in 17$75 \%$ of systemic lupus erythematosus (SLE) patients [66], manifesting as neuropsychiatric systemic lupus erythematosus (NPSLE). A broad range of autoantibodies has been implicated in NPSLE, including those directed against native DNA, ribosomal $\mathrm{P}$ proteins, phospholipids, a proliferation-inducing ligand, and histones. The hallmark anti-DNA antibodies in SLE have generated substantial interest in the context of neuropsychiatric syndromes due to their cross-reactivity with the GluN2 (NR2) subunits of NMDAR. This connection was uncovered by screening a phage display peptide library with the R4A antibody which targets murine double-stranded DNA. From the phage library, a five amino acid consensus sequence, DWEYS, was identified on the GluN2a (NR2a) and GluN2b (NR2b) subunit of NMDAR in residues 283-287 [67] (Fig. 1b). Indeed, screening of serum and CSF identified a proportion of SLE patients that harbor anti-GluN2 (NR2) antibodies [67-70]. While several attempts have been made to correlate anti-GluN2 antibodies with clinical symptoms in patients, the data are inconsistent. Interestingly, anti-NR2 antibodies have also been detected in Rasmussen's encephalitis and chronic progressive epilepsia using western blot [71]. Recently, serum and CSF from patients with focal NPSLE and peripheral involvement were tested against peptide sequences of GluN1 (NR1) subunit of NMDAR [72]. Antibodies recognized an epitope within the $\mathrm{N}$-terminal extracellular domain at aa19-44 and aa56-81 using ELISA (Fig. 2f). However, the relevance of anti-GluN1 antibodies to NPSLE pathogenicity and their conformational epitopes have yet to be determined.

\section{Autoimmune neuromuscular junction disorders}

Antibody-mediated diseases have also been associated with the PNS. Identification of the main autoantigens involved in PNS disorders has preceded many of the autoantigens in CNS disorders, possibly due to the greater accessibility to the PNS or to the now-refuted dogma that the brain was impenetrable to antibodies. However, a number of new targets have been identified for a number of disorders, highlighting ongoing development of autoimmune neurology.

\section{Myasthenia gravis}

Myasthenia gravis (MG) is a peripheral autoimmune neuromuscular junction (NMJ) disorder, one of the 


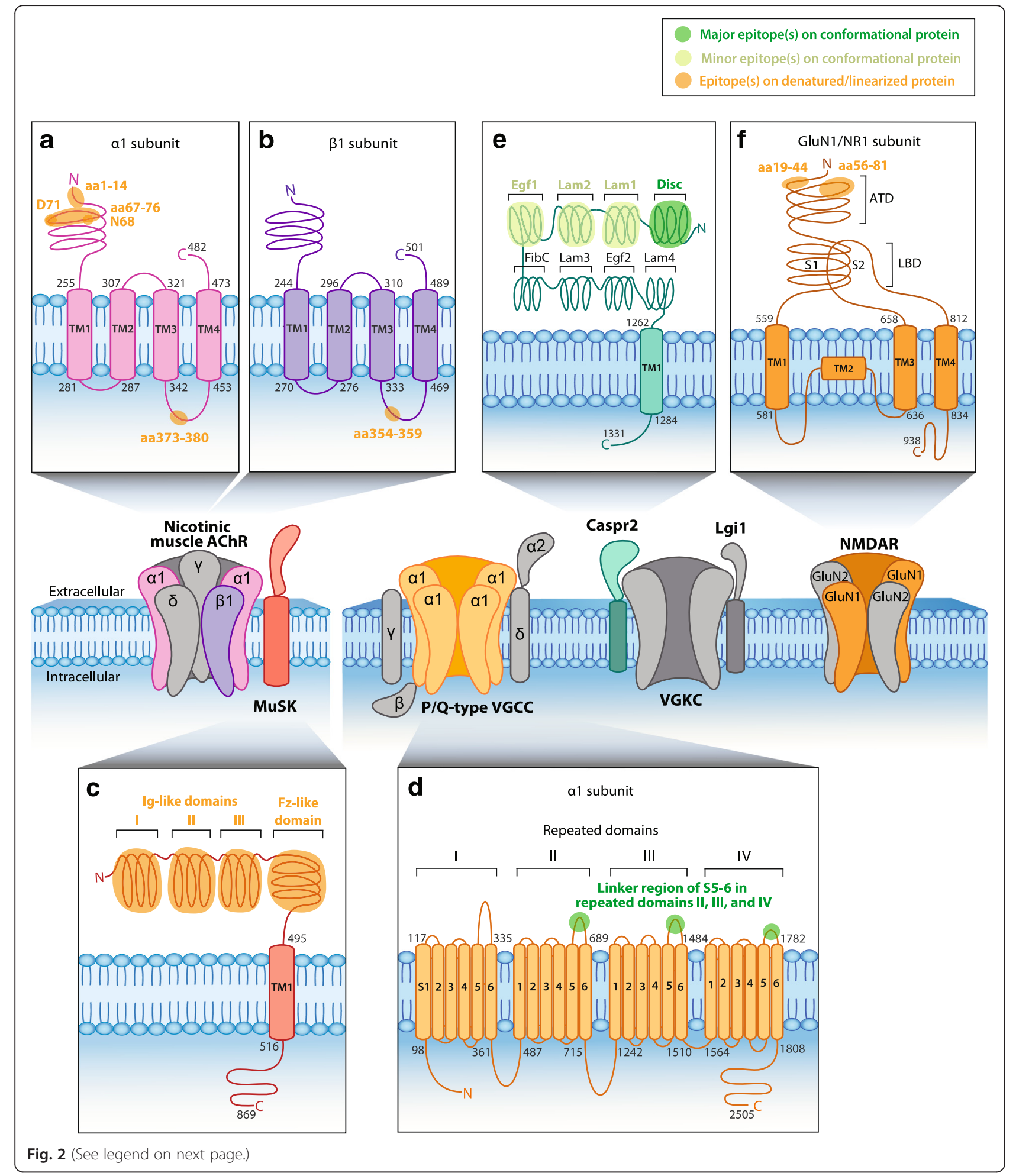


(See figure on previous page.)

Fig. 2 Epitopes of human PNS autoantibodies. Nicotinic muscle acetylcholine receptor (AChR) and muscle-specific kinase (MuSK, O15146) are postsynaptic muscle proteins. Anti-AChR antibodies target an extracellular epitope on the a1 subunit within amino acids (aa)1-14 [79] and aa6776 [33]. Cytoplasmic epitopes have also been mapped in the a1 subunit at aa373-380 (a, P02708) and aa354-359 in the $\beta 1$ subunit (b, P11230) [82]. c MuSK contains three immunoglobulin (Ig)-like domains and a Frizzled (Fz)-like domain. Anti-MuSK antibodies bind to the three N-linked lglike domains and the Fz-like domain [83-85]. $\mathbf{d}$ The neuronal P/Q-type voltage-gated calcium channel (VGCC) consists of four repeated domains, each containing six segments (S), with a linker region between S5 and S6. Anti-P/Q-type VGCC antibodies recognize epitopes in the linker region of repeating domains II-IV [94-96]. e Neuronal anti-contactin-associated protein 2 (Caspr2, Q9UHC6) antibodies recognize the extracellular Nterminal half (domains I-IV) but most commonly bind to an epitope within the discoidin (Disc) domain [37, 38]. f Neuronal N-methyl-D-aspartate receptor (NMDAR) contains an extracellular amino terminal domain (ATD) and a ligand-binding domain (LBD) formed by segment 1 (S1) and segment 2 (S2). Anti-NMDAR antibodies recognize aa19-44 and aa56-81 in the ATD of the GluN1 subunit (f, Q05586) [72]. Human protein topology, i.e., aa sequences and transmembrane domains (TM), is adapted from UniProt database, and UniProt identifiers are shown between brackets. Diagrams do not depict protein crystal structure. Green highlights major (dark green) and minor (light green) epitopes mapped by methods which retain the native in vivo conformational structure of the protein, such as cell-based assays. Orange highlights epitopes determined by methods which denature protein, such as western blots and ELISAs (Table 1)

earliest discovered naturally occurring autoimmune disorders mediated by antibodies. In 1973, antibodies against nicotinic muscle-type AChR were discovered in patient sera and in an experimental model of MG [73, 74]. Anti-AChR antibodies are responsible for pathophysiology in approximately $85 \%$ of MG patients [28, 75], disrupting synaptic differentiation to cause muscle fatigue and weakness. The remainder of patients mainly harbors anti-MuSK antibodies ( 10\%) or antibodies against a more recently identified antigenic target, Lrp4 $(\sim 5 \%)$. While anti-AChR and antiLrp4 antibodies are mutually exclusive in MG, double seropositive cases occur for both anti-AChR or antiLrp4 and anti-MuSK antibodies [76].

Fundamentally, the nicotinic muscle-type AChR is a pentameric transmembrane glycoprotein of stoichiometry $\alpha_{2} \beta \gamma \delta$, in which the subunits are arranged around a central ion pore (Fig. 2). In adult muscle, a $\varepsilon$ subunit occurs in place of the fetal $\gamma$ subunit [77]. B cell epitopes have been identified on all five AChR subunits of fetal and adult forms, and the main immunogenic region is located on the acetylcholine-binding $\alpha 1$ subunit [78]. Early studies mapping the binding sites of anti-AChR antibodies looked at binding between synthetic peptides and rat monoclonal antibodies which recognized AChR from various species, including humans. The main immunogenic region of AChR was localized to aa67-76 on the extracellular loop of the $\alpha 1$ subunit using a solidphase radioimmunoassay where 14-20mers were incubated with the different monoclonal antibodies [33]. The importance of the $\alpha 1$ subunit was then confirmed by competition binding radioimmunoassay examining the adsorption of these monoclonal antibodies by the chosen peptide. Results of a later study indicated that interaction of the main immunogenic loop with aa1-14 on the N-terminal $\alpha$-helix produces a conformational epitope on AChR that significantly augments the degree of antibody binding [79]. The amino acids at positions 68 and 71 appeared to be crucial contact sites, as substitutions of these residues with L-alanine nearly abolished monoclonal antibody binding [80, 81] (Fig. 2a). Autoantibodies against intracellular portions of AChRs have also been detected in MG patients, targeting a variety of subunits [82]. Cytoplasmic epitopes reported thus far include aa373-380 of the $\alpha 1$ subunit (Fig. 2a) and aa354-359 of the $\beta 1$ subunit [82] (Fig. 2b).

The extracellular domain of MuSK, which comprises three $\mathrm{N}$-terminal Ig-like domains and a frizzled (Fz)-like domain (Fig. 2c), has also demonstrated antibody immunoreactivity in MG. A major epitope appears to be contained within the first Ig-like domain, as most antiMuSK sera bind to this domain by ELISA [34, 83]. This result was also shown by earlier studies using radioimmunoassays in which most anti-MuSK patient sera recognized constructs comprising the first two extracellular Ig-like domains of MuSK [84-86]. A proportion of sera also bound to a construct of the combined third Ig-like and Fz-like domains [84] (Fig. 2c). Immunoreactivity to Fz-like domain was also confirmed by ELISA [34]. Further studies are necessary to dissect the binding specificity within each of these regions, particularly the highly immunogenic first Ig-like domain. Evidence from in vitro solid-phase assays suggests that antibodies against Lrp4 disrupt the association between Lrp4 and its ligand, agrin, to impair neuromuscular transmission [30]. It has been speculated that epitopes may be located within two specific LDLa domains in the extracellular region of Lrp4, since these sites normally appear to enhance Lrp4-agrin interaction [76]. However, epitope mapping studies have not yet examined this possibility nor investigated alternative antigenic sites.

Autoantibodies against titin, a large intracellular protein of striated muscle, have been detected and wellstudied in MG patients, mainly those who are positive for anti-AChR antibody with $\sim 40 \%$ of MG patients positive for both antibodies [87]. Double positivity between anti-MuSK and anti-titin, and anti-Lrp4 and antititin antibodies has been detected in $15 \%$ of patients 
[87]. Stergiou et al. have shown that $13 \%$ of triple seronegative MG patients (without anti-AChR, anti-MusK, and anti-Lrp4 antibodies) had anti-titin antibodies [87]. The merit of anti-titin antibody as predictor of disease severity or thymoma in MG has been demonstrated by several investigators [88, 89]. An early study screened a human heart cDNA expression library with serum from five MG patients and mapped epitopes to Ig C2-like and fibronectin type III-like motifs [88]. This $30-\mathrm{kDa}$ segment of titin, called MGT30, is considered the main immunogenic region of titin. MG thymoma patient sera reacted strongly with MGT30-expressing E. coli [87].

\section{Lambert-Eaton myasthenic syndrome}

LEMS has also been shown to cause disruptions at the NMJ, leading to symptoms like proximal muscle weakness and autonomic dysfunction [90]. Eighty-five to ninety percent of LEMS cases are associated with autoantibodies against presynaptic VGCC [91-93], which impair neuromuscular transmission by diminishing the release of acetylcholine. VGCCs consist of four $\alpha 1$ subunits, which form the voltage sensor pore, and accessory subunits $\beta, \alpha 2 / \delta$, and $\gamma$ (Fig. 2). Autoantibodies in LEMS patients mainly target the $\alpha 1$ subunit of $\mathrm{P} / \mathrm{Q}$-type VGCC. The VGCC $\alpha 1$ subunit consists of four repeated domains (I-IV), each with six transmembrane segments (called S1-S6) joined by linker regions. A radioimmunoassay in which synthetic peptides of the linker region between S5 and S6 from the four repeated domains were incubated with LEMS patient sera detected binding to the linker region from domains II and IV [94, 95]. An additional study identified a possible conformational epitope within the linker region between S5 and S6 of domain III [96] (Fig. 2d). Antibodies against the auxiliary $\beta$ subunit, which is anchored to a cytoplasmic region of the $\alpha 1$ subunit of VGCC, have also been detected in a substantial proportion of LEMS patients [97-99].

An additional epitope target in LEMS is the synaptic vesicle protein synaptotagmin I [100]. Anti-synaptotagmin I antibody has been detected in a small proportion of patients, including several that were anti-VGCC antibody negative [93]. Synaptotagmin I localizes to the synaptic vesicle membrane where it functions as a calcium sensor to regulate neurotransmitter release. Despite synaptotagmin membrane location, portions of its $\mathrm{N}$-terminus are likely to be exposed during exocytosis [101], enhancing its accessibility to circulating antibodies.

\section{Acquired neuromyotonia}

Acquired neuromyotonia (NMT), unlike the myasthenic syndromes discussed above, involves an aberrant increase in acetylcholine activity at the NMJ, causing peripheral nerve hyperexcitability. Early studies implicated antibodies against VGKC, which were detected in $40 \%$ of NMT sera [102]. Following this, immunoprecipitation studies using ${ }^{125} \mathrm{I}$ - $\alpha$-dendrotoxin-labeled VGKCs revealed specificity of NMT antibodies towards three Shaker-like $\left(K_{V} 1\right)$ VGKC $\alpha$ subunits, $K_{V} 1.1, K_{V} 1.2$, and $K_{V} 1.6[103,104]$. Because patient sera were shown to bind to recombinant forms of the same three $K_{V} 1$ channel proteins expressed on transfected Xenopus oocytes, it was suggested that a conformational unmapped epitope was located on these subunits [104]. However, recent reevaluation of autoantibody specificity against VGKC by cell-based assays has demonstrated that bound antigens were in fact mostly Caspr2 and sometimes Lgi1 with only a minority of patients binding to $K_{v} 1$ VGKC $[13,15]$. As previously discussed, anti-Caspr2 antibody has been shown to target the extracellular N-terminal domain of Caspr2 (Fig. 2e) [37]. Moreover, findings of anti-VGKC complex antibody-positive NMT patients in which epitope targets are unaccounted for may suggest involvement of other VGKC subunits or unidentified components of the VGKC complex [105].

\section{Autoimmune neuropathies}

The node of Ranvier and the adjacent paranode of myelinated axons contain important cell adhesion molecules including neurofascin and contactin. Contactin interacts with oligodendrocyte-specific neurofascin-155 (NF155) at the paranode via $\mathrm{N}$-glycans, whereas neuron-specific neurofascin-186 (NF186) is localized at the node. The extracellular domains of NF155 and NF186 were observed to be targets of autoantibodies in MS patients, and these autoantibodies have been shown to exacerbate disease in experimental acute encephalomyelitis (EAE) mouse model [26]. Furthermore, anti-neurofascin antibodies have been detected in autoimmune PNS neuropathies, such as chronic inflammatory demyelinating polyneuropathy (CIDP), Guillain-Barre syndrome (GBS), and its variants: acute motor axonal neuropathy (AMAN) and acute inflammatory demyelinating polyradiculoneuropathy (AIPD) [106, 107]. The target epitopes of anti-NF155 and anti-NF186 antibodies in CIDP patients were mapped by cell-based assay to fibronectin type III (Fn) domains Fn3 and Fn4 (Fig. 3a) and Fn5 and Mucin-like domain (Fig. 3b), respectively [107]. Interestingly, CIDP and GBS patients also harbor anti-contactin 1 antibodies [27, 108]. Anti-contactin 1 antibody binding was highly dependent on $\mathrm{N}$-glycosylation in a case series of four CIDP patients, and one patient more specifically targeted N-glycosylated asparagines at positions 467, 473, and 494 [108] (Fig. 3c).

Approximately $60 \%$ of GBS patients also harbor antiganglioside antibodies [109]. Depending on the GBS subtype, these autoantibodies may target the myelin sheath and Schwann cells, or the axons of peripheral nerves [110], and might be pathogenic [111, 112]. 


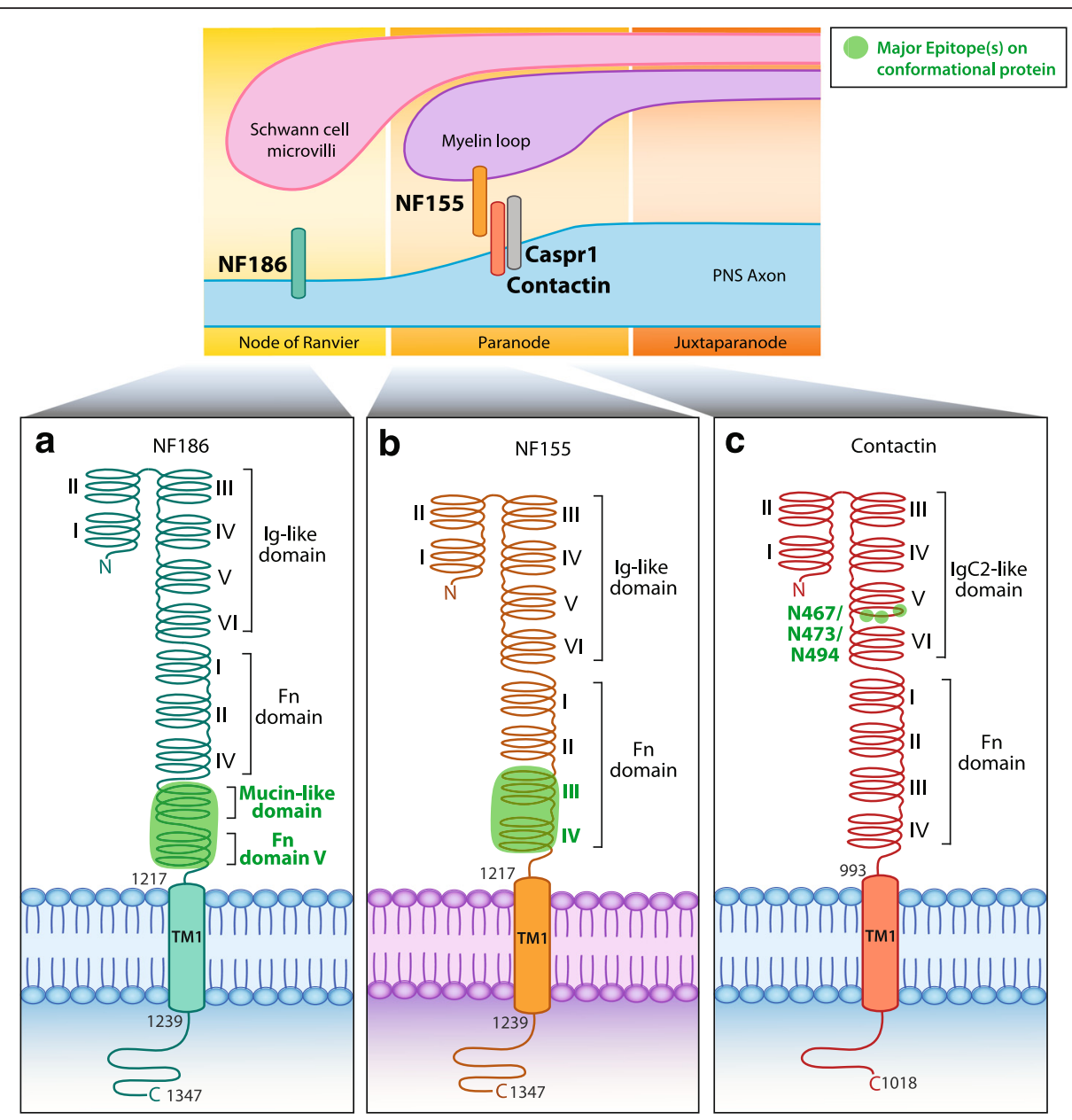

Fig. 3 Epitopes of human PNS autoantibodies at the node of Ranvier. There are two isoforms of neurofascin (NF). a The neuronal isoform NF 186 (NF186, O94856) that resides within the node. b The glial isoform NF 155 (NF155, O94856) that resides on the myelin loop within the paranode. Anti-NF186 antibodies target the extracellular fibronectin type III (Fn) V (or Fn5) and Mucin-like domain. Anti-NF155 antibodies target extracellular domains Fn III (or Fn3) and Fn IV (Fn4) [107]. c Antibodies directed against neuronal contactin (Q12860) target N-glycosylation sites N467, N473, and N494, within the extracellular immunoglobulin (Ig) C2-like domain 5 [108]. Human protein topology, i.e., aa sequences and transmembrane domains (TM), is adapted from UniProt database, and UniProt identifiers are shown between brackets. Diagrams do not depict protein crystal structure. Dark green highlights major epitopes mapped by methods which retain the native in vivo conformational structure of the protein, such as cell-based assays (Table 1)

Gangliosides are a family of sialic acid-containing glycosphingolipids and constitute a viable target for circulating autoantibodies due to their location in the outer leaflet of the cell membrane. IgG antibodies against the ganglioside GM1 were first detected in sera of GBS patients by ELISA [113]. Although anti-GM1 antibodies from the IgG isotype are indeed the most frequently reported in the pure motor variant of GBS [114], autoantibodies targeting different gangliosides appear to correlate with distinct clinical phenotypes [110]. For instance, another form of GBS called Miller-Fisher syndrome is characterized by antibodies against ganglioside GQ1b [115]. More recently, it has been shown that autoantibodies in a small number of GBS patients recognize complexes formed by two different gangliosides, for instance GD1a/
GD1b and GD1a/GM1 [116, 117]. This knowledge has improved anti-ganglioside antibody detection rates and led to reclassification of a small number of patients who were seronegative for autoantibodies against individual gangliosides [116].

Antibodies against nicotinic ganglionic AChR are strongly associated with patients with autoimmune autonomic ganglionopathy (AAG), although they are found in some patients with other autonomic neuropathies [118]. An early study by Vernino et al. found that approximately $50 \%$ of patients with acute or subacute forms of AAG harbor antibodies against ganglionic AChR [119]. However, a later study showed that the clinical associations of autoantibodies against ganglionic AChR may be broader than previously thought, with 
many patients harboring diverse neurological presentations including peripheral neuropathies, dysautonomia, and encephalopathy. Cancers were also found in one third of the examined cohort [120]. Ganglionic AChR can be distinguished from muscle AChR by the presence of two $\alpha 3$ instead of $\alpha 1$ subunits, and increased expression in the peripheral autonomic ganglia, where it is necessary for fast synaptic transmission. While it appears that all seropositive AAG patients have anti-ganglionic AChR antibodies that target the $\alpha 3$ subunit [121], a minor proportion of patients also harbor additional immunoreactivity against the AChR $\beta 4$ subunit [122] that commonly associates with $\alpha 3$. Correlation between ganglionic anti-AChR antibody titers and disease severity and decrease with treatment and clinical improvement [119], as well as animal studies [123, 124], have implied that these antibodies have pathogenic potential. Specific epitopes on gangliosides and ganglionic AChR have not been mapped.

\section{Relevance of identifying the epitopes of autoantibodies}

Currently, the mechanism by which an autoimmune response is initiated is unclear, and where exactly CNS autoantibodies are generated has been a subject of much interest. Studies have shown that disease-associated B cells are found both within the periphery and CNS and that the cells are clonally related, for example in MS [125]. Palanichamy et al. demonstrated that an exchange of immunologically active clusters of related B cells occurs between the CNS and peripheral blood compartments. Also, the majority of $\mathrm{B}$ cell maturation occurs outside the CNS [126]. These recent discoveries highlight the relevance of using patient sera for autoantibody detection and epitope analysis studies, since B cell maturation can occur in the periphery, specifically in the cervical lymph nodes [126].

While mapping of epitope will likely help us understand autoantibody function, conversely it may also be true that an understanding of antibody role, which could influence antigenic function, will help to predict or uncover the epitopes. Overall, knowledge of the autoantibody epitope target may provide valuable insight into the earliest immune mechanisms of autoimmunity, lead to improved diagnosis, allow more precise testing, and enable development of epitope-specific therapies. In addition, determining whether the target epitope is conserved between species, for example, between human and rodent, may have relevance to pathogenic studies in animal models.

\section{Epitope and antibody detection}

Some of the autoantigens detected in the antibodymediated disorders described above can have two or more isoforms. Knowledge of autoantibody isoform specificity may be important for diagnosis and will ensure precise testing. For example, AQP4 has two isoforms, AQP4-M1 and AQP4-M23. Inconsistent diagnostic results have emerged due to the isoform selected for antiAQP4 antibody testing [127-129]. Untagged AQP4-M23 isoform used in a live cell-based assay was the most ideal method, yielding a specificity of $100 \%$ and sensitivity of $74.4 \%$ [130]. Another study found that AQP4M1 cell-based fluorescence assay was the most reliable method for antibody testing and serological diagnosis [131], and another large study did not find significant differences between AQP4-M1 and AQP4-M23 [132]. However, recently, a multi-center study further confirmed the value of using AQP4-M23 isoform for optimal sensitivity [133].

\section{Epitope and antibody pathogenesis}

Autoantibodies targeting extracellular, rather than intracellular, domains of an antigen have a higher probability of being pathogenic by modulating receptor function, which can be studied in vitro and in vivo. However, since epitopes may vary between species, matching epitope targets between human autoantibodies and murine models is important for animal studies. For instance, the majority of patients with anti-MOG antibodies did not recognize conformational intact mMOG [56], whereas epitopes recognized by anti-NMDAR antibodies are similar between the two species [35], or at least share some cross-reactivity as in the case of anti-AQP4 antibodies [62, 134]. Longitudinal studies of autoimmune neurological disorders in humans are necessary to substantiate findings from animal models and determine whether the same mechanisms are relevant to human disease. Based on these results, decisions can be made as to whether the therapies that have proved effective in animal models are translatable to human disorders.

Understanding the antibody epitope will enable inquiry into mechanisms of antibody pathogenic potential. In the case of NMDAR, residues N368/G369 are located within the bottom lobe of ATD, in close proximity to the hinge of the two ATD lobes that are important for receptor physiology. Outside-out single channel recordings were measured, which showed that anti-NMDAR antibody binding prolongs the open time of the receptor. These results suggest that antibodies influence channel function, and knowing where antibodies bound also helped to hypothesize on how they can hinder their target function. Previous studies support antiNMDAR antibody pathogenicity as they can induce receptor internalization $[135,136]$ and alter receptor trafficking [137]. Recently, two studies have endeavored to assess anti-NMDAR antibody pathogenicity in animal models [138, 139]. Planaguma et al. used dialyzed 
patient and control CSF samples before cerebroventricular infusion using osmotic pumps. Upon injection of patient samples, but not control samples, mice developed progressive memory deficits and depressive-like behaviors over the next 18 days but did not have other affected behavioral or locomotor activities [138]. Wright et al. investigated the epileptogenic potential of antiNMDAR antibodies. C57BL/6 mice were also injected intracerebroventricularly, but with purified IgG from CSF of anti-NMDAR antibody-positive patients or healthy controls. Anti-NMDAR IgG antibodies alone did not produce spontaneous seizures. However, when mice were challenged intraperitoneally with chemo-convulsant pentylenetetrazol, mice injected with anti-NMDAR antibodies had more convulsive seizures than healthy controls within 2 days [139]. Although these studies are complementary and commendable, the animal models did not entirely recapitulate human disease phenotype. For example, the movement disorders observed in most anti-NMDAR encephalitis patients were not present in either models, and this illustrates the ambiguity and difficulty in assessing antibody pathogenic mechanisms in vivo.

To evaluate the functional effect of anti-AMPAR antibodies, purified anti-AMPAR IgG antibodies from patients or controls were incubated on primary rat cerebrocortical neurons, and miniature excitatory postsynaptic current (mEPSCs) recordings were measured. Compared to control IgG, it was found that antiAMPAR antibodies altered mEPSCs in cultured neurons [32]. Therefore, binding of anti-AMPAR antibodies to the bottom lobe of ATD may alter the electrophysiology of AMPAR and affect normal function of neuronal receptor upon binding.

Different amino acid recognition can lead to epitopespecific pathogenic effects as in the case of anti-GAD65 antibody, for which pathogenic evidence is mounting [47, 140, 141]. Indeed, antibodies directed to residues 308-365 induce intense and rapidly weaning effects on motor and cognitive functions, and antibodies to residues 451-585 induce sustained medium-sized effects in cerebellum-injected rats [142]. These results have to be discussed in the context of the intracellular location of GAD65, and although the antibody access has not been fully explained yet, the uptake of immunoglobulins into neurons could occur via antigen-dependent or antigenindependent mechanisms [142, 143].

Due to their IgG isotype, some antibodies have the capacity to activate immunological cytotoxic mechanisms. This has been the case for anti-Caspr2 and anti-MOG antibodies in encephalitis and demyelinating disorders, respectively. Indeed, both human anti-Caspr2 and antiMOG antibodies have been shown to activate complement in vitro [50, 144]. However, evidence of anti-MOG antibody pathogenicity in demyelinating disorders is still limited. In vivo and in vitro animal studies indicated that anti-MOG antibodies mediate complement-mediated lysis $[145,146]$. One study suggested a mechanism of cellmediated cytotoxicity, as sera from pediatric samples were found to induce natural killer cell activation to surfaceexpressing MOG [21]. Using MOG-transfected HEK293A cells, another study demonstrated that anti-MOG antibodies, at high titers, are able to activate complement to cause lysis of MOG-expressing cells, whereas antibodies at low titers did not [50]. A more recent study observed loss of cytoskeletal organization in MOG-expressing MO3.13 cells incubated with demyelinating pediatric purified IgG, which contained anti-MOG antibodies [147]. Although the above studies have started to uncover the effector mechanisms of anti-MOG antibodies, how exactly autoantibody binding to its epitope contributes to these mechanisms is yet to be established.

Antibody pathogenicity has also been demonstrated in PNS antibody-mediated disorders. For instance, pathogenicity of anti-AChR antibodies is evidenced by the passive transfer of experimental autoimmune myasthenia gravis (EAMG) following anti-AChR monoclonal antibody injection. Antibodies targeting the AChR main immunogenic region appear to be particularly potent, with one study showing that several different monoclonal antibodies targeting this region of AChR efficiently induced myasthenic symptoms in rats [148]. The monoclonal antibodies used in this study were rat IgG1 or IgG2 against AChR from fish electric organ or mammalian muscle, and each antibody caused an approximate $50 \%$ reduction in AChR quantal content. In contrast, antibodies directed against intracellular portions of the $\alpha 1$ subunit or $\delta$ subunit, and monoclonal antibodies against the extracellular portion of the $\beta 1$ subunit of AChR did not cause EAMG. Further to this, the effects of monoclonal antibodies against the main immunogenic region were not as potent as anti-AChR sera, suggesting that other serum factors play a role in enhancing myasthenic symptoms. These factors may be other IgG subclasses or polyclonal antibodies that target other regions of AChR. As mentioned above, anti-MuSK antibodies target the Ig-like domain 1. Interestingly, that region contains residue I96 that is essential for interaction between MuSK and Lrp4 [149]. Anti-MuSK antibodies could be pathogenic via the prevention of MuSK-Lrp4 binding, either by hindering binding or by modifying MuSK topology. Passive transfer of MuSK MG patient sera or IgG $[84,150,151]$ and the extracellular domain of Lrp4 [152] have demonstrated similar pathogenic effects in mice. In the context of LEMS, injection of a peptide sequence of synaptotagmin containing residues 2053 stimulated antibody production in rats and caused electrophysiological defects at the NMJ, including reduced acetylcholine release [153]. Similarly, animal 
transfer studies involving autoantibodies against Shakerlike VGKC [102] cause aberrations in synaptic transmission. There is further evidence for the autoimmune etiology of NMT in that it may be associated with myasthenic syndromes and SLE.

Purified SLE anti-DNA antibodies following injection into mouse brain also have neurotoxic effects. This effect might occur via their binding to NMDAR as GluN2 blocker MK-801-treated mice had no neuronal injury after antibody injection [67]. Conversely, not all antibodies show pathogenic features, as seen in LEMS. Antibodies are raised against the VGCC $\beta$ subunit in some patients but are unlikely to be a pathogenic factor in LEMS as rats immunized with recombinant $\beta$ subunit fail to develop neuromuscular defects, despite exhibiting high antibody titers [99].

\section{Epitope and potential therapy}

Uncovering the autoantibody epitope target can aid in the development of novel therapies tailored to patient needs including epitope-specific therapies, such as decoy antigen therapy. Decoy antigen therapy is the use of a soluble epitope to block antibody binding to target brain antigen [154, 155]. In the case of EAMG, a therapeutic vaccine consisting of bacterially expressed cytoplasmic domains of human AChR subunits was found to reduce the development of chronic EAMG in rats. The authors found that the mechanism behind the novel therapy was to change the isotype of the antibody response from IgG2b to IgG1. Furthermore, they show that injection of AChR cytoplasmic domains in adjuvant is promising as a safe, effective, antigen-specific, rapidly acting, and long-lasting approach to therapy of MG [156]. Other additional therapeutic strategies attempt to prevent antibody-dependent pathogenicity by a "blocker therapy". Anti-AQP4 rAbs with a mutated Fc region to hinder antibody functionality were utilized in a competition assay with anti-AQP4 antibodies from NMO patient sera. rAbs were capable of blocking AQP4 binding by pathogenic patient antibodies, thereby impeding downstream antibody-mediated complement and cell cytotoxicity in vivo and in vitro $[157,158]$. Uncovering the autoantibody epitope can also aid to understand therapy sensitivity. Indeed, it could be hypothesized that specific epitope patterns could be correlated to therapy responsiveness, and therefore influence patient treatment.

\section{Potential triggers of antibody-mediated autoimmunity}

Currently, it is unclear what initiates autoimmunity. One proposed hypothesis is that ectopic expression of antigens, for example by tumors, would activate autoimmune responses. Ovarian teratoma, found in $50 \%$ of anti-NMDAR encephalitis adult patients, have been shown to express NMDAR [10, 135, 159]. However, these tumors are seldom detected in all patients, especially younger ones, who represent an important group of patients. Another proposed hypothesis is molecular mimicry, a phenomenon whereby infectious microbes express antigens which share structural homology with self-antigens, so immune responses initiated towards microbes may result in a reaction against the body's own antigens $[160,161]$. One study reports the mechanism of cross-reactivity between AQP4 and human Tlymphotropic virus 1 (HTLV-1). After matching one intracellular AQP4 epitope (described in [61]) to a highly similar sequence in the human TAX1BP1 protein involved in HTLV-1 replication, the investigators detected anti-AQP4 antibodies in mice immunized with the TAX1BP1-derived peptide [162]. These results suggest that a latent HTLV-1 infection could lead to TAX1BP1 antigen presentation and the production of anti-AQP4 antibodies, perhaps through $\mathrm{T}$ cell-mediated mechanisms [162]. Further experiments are required to validate these hypotheses in NMO.

Additionally, several studies report a progression to anti-NMDAR encephalitis following herpes simplex virus encephalitis (HSVE). In some cases, patients were initially diagnosed with HSVE, but later progressed to develop anti-NMDAR encephalitis or antiD2R antibody-associated movement and psychiatric disorders that tested positive for anti-NMDAR and anti-D2R antibodies [163-167]. Although these studies have identified a link between HSV and development of autoimmune disorders, whether or not molecular mimicry is involved is still unclear. High neuronal antigen levels could be released during damage to the brain parenchyma after infection by neurotropic herpes simplex virus (HSV), therefore contributing to an activation of an autoimmune response. Additionally, anti-NMDAR encephalitis has also been observed to follow a varicella zoster brain infection in one patient [168]. On the other hand, some autoantibodies, for example anti-D2R antibodies, have been detected in disorders, such as group A Streptococcus-associated Sydenham chorea, that are clearly induced by bacterial infection, and molecular mimicry has been suggested between bacterial antigens and D2R using a rAb isolated from a patient [169]. There is a longstanding hypothesis of molecular mimicry in GBS, as about one quarter of cases are preceded by infection with Campylobacter jejuni [170]. Evidence for this hypothesis arose from a study in rabbits, where animals immunized with C. jejuni-like lipopolysaccharides (LPS) developed antibodies against a panel of ganglioside antigens [171]. The same study found that serum IgG from these rabbits and GBS patients bound gangliosides at the nodes of Ranvier. Molecular mimicry 
between gangliosides on the surface of neurons and C. jejuni LPS has since been supported by mass spectrometry and serological studies. LPS of the C. jejuni strains that cause GBS harbor motifs that resemble GM1, GD1a, and GQ1b gangliosides [172, 173]. Antibodies against other combinations of gangliosides are thought to induce related disorders like Miller-Fisher syndrome [110]. However, the fact that not all GBS patients are reactive to $C$. jejuni suggests that molecular mimicry might not be the only mechanism at play. Overall, determination of possible molecular mimicry relies on a linear comparison between pathogen and autoantigen sequences, and multiple confounders, such as conformational non-linear epitopes and polyclonality, exist, making it a challenging concept to prove.

Additionally, patients with rheumatoid arthritis, MG, LEMS, Crohn's disease, SLE, systemic vasculitis, and IgA nephropathy have all been shown to have altered immunoglobulin glycosylation [174-178]. It has been recently suggested that these $\mathrm{N}$-glycans present within Fc region of the antibody molecule could influence antibody effector function and therefore play a role in autoimmunity, although this concept would need further validation [179].

\section{Potential mechanisms of double autoantibody positivity}

Mapping of autoantibody epitopes has shown that patients, individually or in clusters, can have different recognition patterns. They can recognize either a single dominant epitope, a combination of major and minor epitopes, or multiple different epitopes of the same antigen. The presence of multiple epitopes may suggest that a polyclonal antibody response is active.

The studies discussed in this review have generally reported single autoantibody immunoreactivity associated with its respective disorder. For example, anti-NMDAR antibodies are detected in anti-NMDAR encephalitis. However, several recent studies have reported the presence of double autoantibody positivity in a small number of patients. The phenomenon of double antibody positivity remains an understudied subject and has been observed in both CNS and PNS antibody-mediated disorders. The presence of autoantibodies against multiple antigens, including anti-ganglionic AChR antibody, was first reported in patients with paraneoplastic disorders and may be a potential biomarker to predict cancer [180]. In 2010, a case report of a 56-year-old man with non-paraneoplastic limbic encephalitis was found to be associated with anti-NMDAR and anti-VGKC antibodies [181]. A subgroup of limbic encephalitis patients positive for anti-GABA $\mathrm{R}$ antibody was also found to be positive to other antigens including thyroid peroxidase (TPO), GAD65, sex determining region Ybox 1 (SOX1), or N-type VGCC [16]. Anti-GABA ${ }_{B} R$ antibodies have also been observed in anti-GAD65 antibody-positive patients with paraneoplastic syndromes [182]. Multiple antibody positivity associated with cancer has been reported in several studies [182, 183]. Petit-Pedrol et al. (2014) recently reported five cases of anti-GABA $\mathrm{A}_{\mathrm{A}} \mathrm{R}$ and anti-GAD65 antibodies co-occurring in CSF and serum [17], and a single case report of a female with encephalitis was found to harbor anti$\mathrm{GABA}_{\mathrm{A}} \mathrm{R}$ and anti-GAD65 antibodies in CSF and serum [184]. Other double antibody positivity combinations that have been identified are anti-NMDAR and anti-GAD antibodies [185], anti-NMDAR and anti-D2R $[165,186]$, anti-GABA ${ }_{B} \mathrm{R}$ and anti-Hu [187], and antiCaspr2 and anti-Lgi1 in a patient with Morvan syndrome [188]. Recently, patients positive for anti-MOG and anti-NMDAR antibodies were reported [189], and later on, double antibody positivity for anti-NMDAR and anti-GlyR and anti-MOG and anti-GlyR antibodies were also shown in two patients [190]. One study even reported triple antibody positivity, including anti$\mathrm{GABA}_{\mathrm{B}} \mathrm{R}$, anti-Hu, and anti-NMDAR antibodies [187].

The occurrence of MG in LEMS patients is a widely accepted phenomenon [191]. Although diagnosis of MG in LEMS individuals has mainly been based on clinical presentation, tests for serum autoantibodies against AChR and VGCC revealed a number of double seropositive cases [192-194]. A case of triple antibody seropositivity has also been identified with anti-AChR, anti-VGKC, and antiMuSK antibodies in a patient with MG and Morvan's syndrome which is commonly associated with VGKC [195]. In SLE, one third of patients have anti-NMDAR antibodies [196]. In addition, a cancer-positive LEMS patient double positive for anti-VGCC and anti-GABA ${ }_{B} R$ antibodies has been reported [197]. The coexistence of multiple anti-ganglioside antibodies is not uncommon, for instance, anti-GM1 and anti-GM1b in GBS patients [198]. Additionally, examples of seropositivity exist for antiganglioside antibodies together with other antibodies. One study indirectly detected immunoreactivity against nicotinic AChR in GBS patient serum, with the finding that serum interfered with the postsynaptic transmission of nicotinic AChR [199]. Anti-VGKC antibodies have been found along with antibodies against ganglioside GQ1b in variants of GBS [200].

These cases of double or multi-antibody positivity are interesting, although mechanisms behind this polyimmunoreactivity have not been elucidated. Underlying tumors could drive the generation of additional antibody seropositivity [180, 197]. Another possibility is the concurrence of two single antibody-specific disorders in the same patient, which is more likely the case for double anti-NMDAR and anti-MOG antibody and anti-AChR 
and anti-AQP4 antibody positivity [166, 201]. Multiantibody positivity may be explained by the concept known as epitope spreading, in which persistent recognition and activation to self-antigens lead to chronic immune system activation [202]. Epitope spreading within the same antigen (intramolecular) or to different antigens (intermolecular) has predominantly been observed in animal models, particularly experimental autoimmune models of EAE and EAMG [203, 204]. Early reports of intermolecular epitope spreading date from the 1990s. Epitope spreading was reported in several mice models of MS, including (SJLxPL)F1, relapsing EAE (R-EAE), SJL/J, B10.PL, and Theiler's murine encephalomyelitis virus-induced demyelinating disease (TMEV-IDD) [204-208]. The mechanism behind epitope spreading is unknown, but it has been suggested that local antigen presenting cells, such as dendritic cells, would initiate epitope spreading in CNS by activating naïve $T$ cells [204]. EAMG can be induced by immunization of organisms with AChR, yielding humoral and cellular responses. When rats were immunized with a recombinant fragment of the extracellular AChR $\alpha$ subunit to induce EAMG, antibodies directed against a hidden intracellular loop of the subunit were detected in two of the immunized animals several weeks after an initial response to the extracellular portion [203]. The fact that the presence of antibodies against the intracellular epitope corresponded to increased disease severity in these animals suggests that epitope specificity may be an important determinant of disease outcomes.

In humans, epitope spreading has also been observed in pediatric MS [209]. Serum samples were collected in children with acquired CNS demyelinating syndromes (ADS) at time of initial attack, and at follow-up at 3 months when children were categorized to either have pediatric MS (ADS-MS) or a monophasic illness (ADSmono). Immunoreactivity of patient serum samples was tested against a panel of $48 \mathrm{CNS}$ antigens, including MOG, myelin basin protein (MBP), proteolipid protein, and CNPase. At initial attack, serum antibody pattern between ADS-MS and ADS-mono patients reacted to similar number of CNS antigens. After 3 months, ADSMS patients reacted against a greater number of CNS antigens and bound to different epitopes within these antigens, while ADS-mono samples demonstrated a reduction in CNS antibody response [209]. This evidence is suggestive of intra- and intermolecular epitope spreading in patients with ADS-MS. Epitope spreading has also been observed in a third of anti-AQP4 antibody-positive patients $(7 / 20)$ over a 15-year follow-up, whereas the majority (13/20) maintained a stable antibody binding pattern [65]. Additionally, in a 5-year longitudinal study on 11 patients harboring anti-MOG antibodies, there was constant epitope recognition with little evidence of intramolecular epitope spreading [56]. This was also observed in MG patients. A recent study examining antiMuSK antibody-positive MG sera found that intramolecular epitope spreading was relatively uncommon within a minimum of 5 years of follow-up. However, when it occurred, immunoreactivity "spread" from the first and second Ig-like domains to the Fz-like domain [34].

Whether epitope spreading occurs over time and in which time frame is therefore important to determine. Such knowledge may prove useful in designing appropriate immunotherapies, like monoclonal antibodies or blocker peptides that bind specific epitopes at different stages of progression.

\section{Conclusions}

As the field of antibody-mediated immune disorders continues to expand and as methodological practices improve, it is expected that the number of antibodypositive patients will rise and that new autoantigens will also be discovered. Numerous cases of patients who present with clinical features similar to antibody-positive patients have been reported, yet upon serological testing, they remain antibody-negative, suggesting the likelihood of unknown antigenic targets or other yet undescribed immunological pathways that could be $\mathrm{T}$ cell-driven. Our current understanding of antibody-mediated disorders and their antibody targets may assist in discovering not only other potential autoantigens but also their epitopes. For instance, NMDAR and AMPAR are ionotropic receptors with similar structure, and their target epitopes are located within the extracellular ATD. Another important ionotropic receptor is kainate receptor. The kainate receptors are a subtype of the ionotropic glutamate receptor. They are involved in synaptic transmission and contribute to postsynaptic excitatory currents in cortex, hippocampus, retina, and spinal cord. Extrapolating from the autoantigens already identified, we may be able to infer other potential autoantigens and their autoantibody epitope.

As mentioned, patients can harbor autoantibodies that target two different antigens, and some patient antibodies have been shown to recognize multiple epitopes of a single antigen. Mechanisms underlying these two occurrences remain unclear. Patients with double antibody positivity may be difficult to assess when it comes to diagnosis and treatment options. It is also unknown whether a polyclonal antibody response may be due to epitope spreading or ectopic antigen expression, and longitudinal analyses, as well as thorough clinical investigations, may help to investigate these phenomena. Future studies will also be needed to investigate whether the epitope specificity is similar between CSF and serum of patients. Greater knowledge of the epitope involved in autoantibody binding may ensure that appropriate 


\section{therapies are administered and, in doing so, improve pa- tient care.}

\section{Acknowledgements}

Not applicable.

\section{Funding}

The authors received funding from the Australian National Health and Medical Research Council (NHMRC), Multiple Sclerosis Research Australia, Star Scientific Foundation, Tourette Syndrome Association (USA), and the Petre Foundation (AU).

\section{Availability of data and materials}

The results supporting the conclusions of this review are published and have been fully referenced in the reference list.

\section{Authors' contributions}

NS and TN performed literature review and drafted the paper under supervision of FB. FT graphed the illustrations. All authors discussed and edited the manuscript. All authors read and approved the final manuscript.

\section{Competing interests}

The authors declare that they have no competing interests.

\section{Consent for publication}

Not applicable.

\section{Ethics approval and consent to participate}

This review summarizes published studies involving human material. Research studies included in this work were approved by appropriate ethics committees.

\section{Received: 11 May 2016 Accepted: 17 August 2016}

\section{Published online: 30 August 2016}

\section{References}

1. Irani SR, Gelfand JM, Al-Diwani A, Vincent A. Cell-surface central nervous system autoantibodies: clinical relevance and emerging paradigms. Ann Neurol. 2014;76:168-84.

2. McKeon A, Pittock SJ. Paraneoplastic encephalomyelopathies: pathology and mechanisms. Acta Neuropathol. 2011;122:381-400.

3. Vincent A, Bien CG, Irani SR, Waters P. Autoantibodies associated with diseases of the CNS: new developments and future challenges. Lancet Neurol. 2011;10:759-72.

4. Coutinho E, Harrison P, Vincent A. Do neuronal autoantibodies cause psychosis? A neuroimmunological perspective. Biol Psychiatry. 2014;75:269-75.

5. Mohammad SS, Ramanathan S, Brilot F, Dale RC. Autoantibody-associated movement disorders. Neuropediatrics. 2013;44:336-45.

6. Graus F, Saiz A, Dalmau J. Antibodies and neuronal autoimmune disorders of the CNS. J Neurol. 2010;257:509-17.

7. Lancaster E, Dalmau J. Neuronal autoantigens_-pathogenesis, associated disorders and antibody testing. Nat Rev Neurol. 2012;8:380-90.

8. Ramanathan S, Mohammad SS, Brilot F, Dale RC. Autoimmnue encephalitis: recent updates and emerging challenges. J Clin Neurosci. 2013;21:722-30.

9. Sinmaz N, Amatoury M, Merheb V, Ramanathan S, Dale RC, Brilot F. Autoantibodies in movement and psychiatric disorders: updated concepts in detection methods, pathogenicity, and CNS entry. Ann N Y Acad Sci. 2015;1351:22-38.

10. Dalmau J, Tuzun E, Wu HY, Masjuan J, Rossi JE, Voloschin A, Baehring JM, Shimazaki H, Koide R, King D, et al. Paraneoplastic anti-N-methyl-D-aspartate receptor encephalitis associated with ovarian teratoma. Ann Neurol. 2007; 61:25-36.

11. Lai M, Hughes EG, Peng X, Zhou L, Gleichman AJ, Shu H, Mata S, Kremens $D$, Vitaliani R, Geschwind MD, et al. AMPA receptor antibodies in limbic encephalitis alter synaptic receptor location. Ann Neurol. 2009:65:424-34.

12. Hutchinson M, Waters P, McHugh J, Gorman G, O'Riordan S, Connolly S, Hager H, Yu P, Becker CM, Vincent A. Progressive encephalomyelitis, rigidity, and myoclonus: a novel glycine receptor antibody. Neurology. 2008;71: $1291-2$.

13. Irani SR, Alexander S, Waters P, Kleopa KA, Pettingill P, Zuliani L, Peles E, Buckley C, Lang B, Vincent A. Antibodies to Kv1 potassium channel-complex proteins leucine-rich, glioma inactivated 1 protein and contactin-associated protein-2 in limbic encephalitis, Morvan's syndrome and acquired neuromyotonia. Brain. 2010;133:2734-48.

14. Lai M, Huijbers MG, Lancaster E, Graus F, Bataller L, Balice-Gordon R, Cowell JK, Dalmau J. Investigation of LGI1 as the antigen in limbic encephalitis previously attributed to potassium channels: a case series. Lancet Neurol. 2010;9:776-85.

15. Lancaster E, Huijbers MG, Bar V, Boronat A, Wong A, Martinez-Hernandez E, Wilson C, Jacobs D, Lai M, Walker RW, et al. Investigations of caspr2, an autoantigen of encephalitis and neuromyotonia. Ann Neurol. 2011;69:303-11.

16. Lancaster E, Lai M, Peng X, Hughes E, Constantinescu R, Raizer J, Friedman D, Skeen MB, Grisold W, Kimura A, et al. Antibodies to the GABA(B) receptor in limbic encephalitis with seizures: case series and characterisation of the antigen. Lancet Neurol. 2010;9:67-76.

17. Petit-Pedrol M, Armangue T, Peng X, Bataller L, Cellucci T, Davis R, McCracken L, Martinez-Hernandez E, Mason WP, Kruer MC, et al. Encephalitis with refractory seizures, status epilepticus, and antibodies to the GABAA receptor: a case series, characterisation of the antigen, and analysis of the effects of antibodies. Lancet Neurol. 2014;13:276-86.

18. Lancaster E, Martinez-Hernandez E, Titulaer MJ, Boulos M, Weaver S, Antoine JC, Liebers E, Kornblum C, Bien CG, Honnorat J, et al. Antibodies to metabotropic glutamate receptor 5 in the Ophelia syndrome. Neurology. 2011;77:1698-701.

19. Boronat A, Gelfand JM, Gresa-Arribas N, Jeong HY, Walsh M, Roberts K, Martinez-Hernandez E, Rosenfeld MR, Balice-Gordon R, Graus F, et al. Encephalitis and antibodies to dipeptidyl-peptidase-like protein-6, a subunit of Kv4.2 potassium channels. Ann Neurol. 2013;73:120-8.

20. Dale RC, Merheb V, Pillai S, Wang D, Cantrill L, Murphy TK, Ben-Pazi H, Varadkar S, Aumann TD, Horne MK, et al. Antibodies to surface dopamine-2 receptor in autoimmune movement and psychiatric disorders. Brain. 2012; 135:3453-68.

21. Brilot F, Dale RC, Selter RC, Grummel V, Kalluri SR, Aslam M, Busch V, Zhou D, Cepok S, Hemmer B. Antibodies to native myelin oligodendrocyte glycoprotein in children with inflammatory demyelinating central nervous system disease. Ann Neurol. 2009:66:833-42.

22. McLaughlin KA, Chitnis T, Newcombe J, Franz B, Kennedy J, McArdel S, Kuhle J, Kappos L, Rostasy K, Pohl D, et al. Age-dependent B cell autoimmunity to a myelin surface antigen in pediatric multiple sclerosis. J Immunol. 2009:183:4067-76.

23. O'Connor KC, McLaughlin KA, De Jager PL, Chitnis T, Bettelli E, Xu C, Robinson WH, Cherry SV, Bar-Or A, Banwell B, et al. Self-antigen tetramers discriminate between myelin autoantibodies to native or denatured protein Nat Med. 2007:13:211-7.

24. Lennon VA, Kryzer TJ, Pittock SJ, Verkman AS, Hinson SR. IgG marker of optic-spinal multiple sclerosis binds to the aquaporin-4 water channel. J Exp Med. 2005:202:473-7.

25. Solimena M, Folli F, Denis-Donini S, Comi GC, Pozza G, De Camilli P, Vicari AM. Autoantibodies to glutamic acid decarboxylase in a patient with stiffman syndrome, epilepsy, and type I diabetes mellitus. N Engl J Med. 1988; 318:1012-20.

26. Mathey EK, Derfuss T, Storch MK, Williams KR, Hales K, Woolley DR, Al-Hayan A, Davies SN, Rasband MN, Olsson T, et al. Neurofascin as a novel target for autoantibody-mediated axonal injury. J Exp Med. 2007;204:2363-72.

27. Querol L, Nogales-Gadea G, Rojas-Garcia R, Martinez-Hernandez E, DiazManera J, Suarez-Calvet X, Navas M, Araque J, Gallardo E, Illa I. Antibodies to contactin-1 in chronic inflammatory demyelinating polyneuropathy. Ann Neurol. 2013;73:370-80.

28. Lindstrom JM, Seybold ME, Lennon VA, Whittingham S, Duane DD. Antibody to acetylcholine receptor in myasthenia gravis. Prevalence, clinical correlates, and diagnostic value. Neurology. 1976;26:1054-9.

29. Hoch W, McConville J, Helms S, Newsom-Davis J, Melms A, Vincent A. Auto-antibodies to the receptor tyrosine kinase MuSK in patients with myasthenia gravis without acetylcholine receptor antibodies. Nat Med. 2001;7:365-8

30. Higuchi O, Hamuro J, Motomura M, Yamanashi Y. Autoantibodies to lowdensity lipoprotein receptor-related protein 4 in myasthenia gravis. Ann Neurol. 2011;69:418-22.

31. Kim Yl, Neher E. IgG from patients with Lambert-Eaton syndrome blocks voltage-dependent calcium channels. Science. 1988;239:405-8.

32. Gleichman AJ, Panzer JA, Baumann BH, Dalmau J, Lynch DR. Antigenic and mechanistic characterization of anti-AMPA receptor encephalitis. Ann Clin Transl Neurol. 2014;1:180-9. 
33. Tzartos SJ, Kokla A, Walgrave SL, Conti-Tronconi BM. Localization of the main immunogenic region of human muscle acetylcholine receptor to residues 67-76 of the alpha subunit. Proc Natl Acad Sci U S A. 1988;85: 2899-903.

34. Huijbers MG, Vink AF, Niks EH, Westhuis RH, van Zwet EW, de Meel RH, Rojas-Garcia R, Diaz-Manera J, Kuks JB, Klooster R, et al. Longitudinal epitope mapping in MuSK myasthenia gravis: implications for disease severity. J Neuroimmunol. 2016;291:82-8.

35. Gleichman AJ, Spruce LA, Dalmau J, Seeholzer SH, Lynch DR. Anti-NMDA receptor encephalitis antibody binding is dependent on amino acid identity of a small region within the GluN1 amino terminal domain. J Neurosci. 2012;32:11082-94.

36. Joubert B, Kerschen $P$, Zekeridou A, Desestret V, Rogemond V, Chaffois MO, Ducray F, Larrue V, Daubail B, Idbaih A, et al. Clinical spectrum of encephalitis associated with antibodies against the alpha-amino-3-hydroxy5-methyl-4-isoxazolepropionic acid receptor: case series and review of the literature. JAMA Neurol. 2015:72:1163-9.

37. Olsen AL, Lai Y, Dalmau J, Scherer SS, Lancaster E. Caspr2 autoantibodies target multiple epitopes. Neurol Neuroimmunol Neuroinflamm. 2015;2:e127.

38. Pinatel D, Hivert B, Boucraut J, Saint-Martin M, Rogemond V, Zoupi L, Karagogeos D, Honnorat J, Faivre-Sarrailh C. Inhibitory axons are targeted in hippocampal cell culture by anti-Caspr2 autoantibodies associated with limbic encephalitis. Front Cell Neurosci. 2015;9:265.

39. Giometto B, Miotto D, Faresin F, Argentiero V, Scaravilli T, Tavolato B. Antigabaergic neuron autoantibodies in a patient with stiff-man syndrome and ataxia. J Neurol Sci. 1996;143:57-9.

40. Honnorat J, Saiz A, Giometto B, Vincent A, Brieva L, de Andres C, Maestre J, Fabien N, Vighetto A, Casamitjana R, et al. Cerebellar ataxia with antiglutamic acid decarboxylase antibodies: study of 14 patients. Arch Neurol. 2001;58:225-30.

41. Malter MP, Helmstaedter C, Urbach H, Vincent A, Bien CG. Antibodies to glutamic acid decarboxylase define a form of limbic encephalitis. Ann Neurol. 2010;67:470-8.

42. Peltola J, Kulmala P, Isojarvi J, Saiz A, Latvala K, Palmio J, Savola K, Knip M, Keranen T, Graus F. Autoantibodies to glutamic acid decarboxylase in patients with therapy-resistant epilepsy. Neurology. 2000;55:46-50.

43. Bu DF, Erlander MG, Hitz BC, Tillakaratne NJ, Kaufman DL, WagnerMcPherson CB, Evans GA, Tobin AJ. Two human glutamate decarboxylases, 65-kDa GAD and 67-kDa GAD, are each encoded by a single gene. Proc Natl Acad Sci U S A. 1992;89:2115-9.

44. Erlander MG, Tillakaratne NJ, Feldblum S, Patel N, Tobin AJ. Two genes encode distinct glutamate decarboxylases. Neuron. 1991;7:91-100.

45. Richter W, Endl J, Eiermann TH, Brandt M, Kientsch-Engel R, Thivolet C, Jungfer $\mathrm{H}$, Scherbaum WA. Human monoclonal islet cell antibodies from a patient with insulin-dependent diabetes mellitus reveal glutamate decarboxylase as the target antigen. Proc Natl Acad Sci U S A. 1992;89: 8467-71.

46. Schwartz HL, Chandonia JM, Kash SF, Kanaani J, Tunnell E, Domingo A, Cohen FE, Banga JP, Madec AM, Richter W, Baekkeskov S. High-resolution autoreactive epitope mapping and structural modeling of the $65 \mathrm{kDa}$ form of human glutamic acid decarboxylase. J Mol Biol. 1999;287:983-99.

47. Raju R, Foote J, Banga JP, Hall TR, Padoa CJ, Dalakas MC, Ortqvist E, Hampe CS. Analysis of GAD65 autoantibodies in Stiff-Person syndrome patients. J Immunol. 2005;175:7755-62.

48. Fouka P, Alexopoulos H, Akrivou S, Trohatou O, Politis PK, Dalakas MC GAD65 epitope mapping and search for novel autoantibodies in GAD associated neurological disorders. J Neuroimmunol. 2015;281:73-7.

49. Kitley J, Woodhall M, Waters P, Leite MI, Devenney E, Craig J, Palace J, Vincent A. Myelin-oligodendrocyte glycoprotein antibodies in adults with a neuromyelitis optica phenotype. Neurology. 2012;79:1273-7.

50. Mader S, Gredler V, Schanda K, Rostasy K, Dujmovic I, Pfaller K, Lutterotti A, Jarius S, Di Pauli F, Kuenz B, et al. Complement activating antibodies to myelin oligodendrocyte glycoprotein in neuromyelitis optica and related disorders. J Neuroinflammation. 2011;8:184.

51. Ramanathan S, Dale RC, Brilot F. Anti-MOG antibody: the history, clinical phenotype, and pathogenicity of a serum biomarker for demyelination. Autoimmun Rev. 2016;15:307-24.

52. Sato DK, Nakashima I, Takahashi T, Misu T, Waters P, Kuroda H, Nishiyama S, Suzuki C, Takai Y, Fujihara K, et al. Aquaporin-4 antibody-positive cases beyond current diagnostic criteria for NMO spectrum disorders. Neurology. 2013;80:2210-6.
53. Kim SM, Woodhall MR, Kim JS, Kim SJ, Park KS, Vincent A, Lee KW, Waters P. Antibodies to MOG in adults with inflammatory demyelinating disease of the CNS. Neurol Neuroimmunol Neuroinflamm. 2015;2:e163.

54. Lalive PH, Menge T, Delarasse C, Della Gaspera B, Pham-Dinh D, Villoslada P, von Budingen $\mathrm{HC}$, Genain CP. Antibodies to native myelin oligodendrocyte glycoprotein are serologic markers of early inflammation in multiple sclerosis. Proc Natl Acad Sci U S A. 2006;103:2280-5.

55. Zhou D, Srivastava R, Nessler S, Grummel V, Sommer N, Bruck W, Hartung HP, Stadelmann C, Hemmer B. Identification of a pathogenic antibody response to native myelin oligodendrocyte glycoprotein in multiple sclerosis. Proc Natl Acad Sci U S A. 2006;103:19057-62.

56. Mayer MC, Breithaupt C, Reindl M, Schanda K, Rostasy K, Berger T, Dale RC, Brilot F, Olsson T, Jenne $D$, et al. Distinction and temporal stability of conformational epitopes on myelin oligodendrocyte glycoprotein recognized by patients with different inflammatory central nervous system diseases. J Immunol. 2013;191:3594-604.

57. Lennon VA, Wingerchuk DM, Kryzer TJ, Pittock SJ, Lucchinetti CF, Fujihara K, Nakashima I, Weinshenker BG. A serum autoantibody marker of neuromyelitis optica: distinction from multiple sclerosis. Lancet. 2004;364: 2106-12.

58. Wingerchuk DM, Lennon VA, Lucchinetti CF, Pittock SJ, Weinshenker BG The spectrum of neuromyelitis optica. Lancet Neurol. 2007;6:805-15.

59. Iorio R, Fryer JP, Hinson SR, Fallier-Becker P, Wolburg H, Pittock SJ, Lennon VA. Astrocytic autoantibody of neuromyelitis optica (NMO-lgG) binds to aquaporin-4 extracellular loops, monomers, tetramers and high order arrays. J Autoimmun. 2013:40:21-7.

60. Nicchia GP, Mastrototaro M, Rossi A, Pisani F, Tortorella C, Ruggieri M, Lia A, Trojano M, Frigeri A, Svelto M. Aquaporin-4 orthogonal arrays of particles are the target for neuromyelitis optica autoantibodies. Glia. 2009:57:1363-73.

61. Kampylafka El, Routsias JG, Alexopoulos H, Dalakas MC, Moutsopoulos HM, Tzioufas AG. Fine specificity of antibodies against AQP4: epitope mapping reveals intracellular epitopes. J Autoimmun. 2011;36:221-7.

62. Pisani F, Mastrototaro M, Rossi A, Nicchia GP, Tortorella C, Ruggieri M, Trojano M, Frigeri A, Svelto M. Identification of two major conformational aquaporin-4 epitopes for neuromyelitis optica autoantibody binding. J Biol Chem. 2011;286:9216-24.

63. Pisani F, Mola MG, Simone L, Rosito S, Alberga D, Mangiatordi GF, Lattanzi G, Nicolotti O, Frigeri A, Svelto M, Nicchia GP. Identification of a point mutation impairing the binding between aquaporin-4 and neuromyelitis optica autoantibodies. J Biol Chem. 2014;289:30578-89.

64. Owens GP, Ritchie A, Rossi A, Schaller K, Wemlinger S, Schumann H, Shearer A, Verkman AS, Bennett $J$ L. Mutagenesis of the aquaporin 4 extracellular domains defines restricted binding patterns of pathogenic neuromyelitis optica lgG. J Biol Chem. 2015;290:12123-34.

65. Tuller F, Holzer H, Schanda K, Aboulenein-Djamshidian F, Hoftberger R, Khalil M, Seifert-Held T, Leutmezer F, Berger T, Reindl M. Characterization of the binding pattern of human aquaporin-4 autoantibodies in patients with neuromyelitis optica spectrum disorders. J Neuroinflammation. 2016;13:176.

66. Stojanovich L, Zandman-Goddard G, Pavlovich S, Sikanich N. Psychiatric manifestations in systemic lupus erythematosus. Autoimmun Rev. 2007:6:421-6.

67. DeGiorgio LA, Konstantinov KN, Lee SC, Hardin JA, Volpe BT, Diamond B. A subset of lupus anti-DNA antibodies cross-reacts with the NR2 glutamate receptor in systemic lupus erythematosus. Nat Med. 2001;7:1189-93.

68. Husebye ES, Sthoeger ZM, Dayan M, Zinger H, Elbirt D, Levite M, Mozes E. Autoantibodies to a NR2A peptide of the glutamate/NMDA receptor in sera of patients with systemic lupus erythematosus. Ann Rheum Dis. 2005;64: 1210-3.

69. Omdal R, Brokstad K, Waterloo K, Koldingsnes W, Jonsson R, Mellgren SI. Neuropsychiatric disturbances in SLE are associated with antibodies against NMDA receptors. Eur J Neurol. 2005;12:392-8.

70. Yoshio T, Onda K, Nara H, Minota S. Association of lgG anti-NR2 glutamate receptor antibodies in cerebrospinal fluid with neuropsychiatric systemic lupus erythematosus. Arthritis Rheum. 2006;54:675-8.

71. Takahashi Y, Mori H, Mishina M, Watanabe M, Kondo N, Shimomura J, Kubota Y, Matsuda K, Fukushima K, Shiroma N, et al. Autoantibodies and cell-mediated autoimmunity to NMDA-type GluRepsilon2 in patients with Rasmussen's encephalitis and chronic progressive epilepsia partialis continua. Epilepsia. 2005;46 Suppl 5:152-8.

72. Ogawa E, Nagai T, Sakuma Y, Arinuma Y, Hirohata S. Association of antibodies to the NR1 subunit of N-methyl-D-aspartate receptors with 
neuropsychiatric systemic lupus erythematosus. Mod Rheumatol. 2016;26: 377-83.

73. Bender AN, Ringel SP, Engel WK, Daniels MP, Vogel Z. Myasthenia gravis: a serum factor blocking acetylcholine receptors of the human neuromuscular junction. Lancet. 1975;1:607-9.

74. Patrick J, Lindstrom J. Autoimmune response to acetylcholine receptor. Science. 1973;180:871-2.

75. Vincent A, Palace J, Hilton-Jones D. Myasthenia gravis. Lancet. 2001;357: 2122-8.

76. Huijbers MG, Lipka AF, Plomp JJ, Van der Maarel SM, Verschuuren JJ. Pathogenic immune mechanisms at the neuromuscular synapse: the role of specific antibody-binding epitopes in myasthenia gravis. J Intern Med. 2014; 275:12-26.

77. Tzartos SJ, Barkas T, Cung MT, Mamalaki A, Marraud M, Orlewski P, Papanastasiou D, Sakarellos C, Sakarellos-Daitsiotis M, Tsantili P, Tsikaris V. Anatomy of the antigenic structure of a large membrane autoantigen, the muscle-type nicotinic acetylcholine receptor. Immunol Rev. 1998;163:89-120.

78. Tzartos SJ, Seybold ME, Lindstrom JM. Specificities of antibodies to acetylcholine receptors in sera from myasthenia gravis patients measured by monoclonal antibodies. Proc Natl Acad Sci U S A. 1982;79:188-92.

79. Luo J, Taylor P, Losen M, de Baets MH, Shelton GD, Lindstrom J. Main immunogenic region structure promotes binding of conformationdependent myasthenia gravis autoantibodies, nicotinic acetylcholine receptor conformation maturation, and agonist sensitivity. J Neurosci. 2009; 29:13898-908

80. Papadouli I, Potamianos S, Hadjidakis I, Bairaktari E, Tsikaris V, Sakarellos C, Cung MT, Marraud M, Tzartos SJ. Antigenic role of single residues within the main immunogenic region of the nicotinic acetylcholine receptor. Biochem J. 1990:269:239-45.

81. Wahlsten JL, Lindstrom JM, Ostlie N, Wu XD, Conti-Tronconi BM. Myasthenia gravis: effect on antibody binding of conservative substitutions of amino acid residues forming the main immunogenic region of the nicotinic acetylcholine receptor. J Recept Res. 1993;13:863-79.

82. Tzartos SJ, Remoundos M. Detection of antibodies directed against the cytoplasmic region of the human acetylcholine receptor in sera from myasthenia gravis patients. Clin Exp Immunol. 1999;116:146-52.

83. Huijbers MG, Zhang W, Klooster R, Niks EH, Friese MB, Straasheijm KR, Thijssen PE, Vrolijk H, Plomp JJ, Vogels P, et al. MuSK IgG4 autoantibodies cause myasthenia gravis by inhibiting binding between MuSK and Lrp4. Proc Natl Acad Sci U S A. 2013;110:20783-8.

84. McConville J, Farrugia ME, Beeson D, Kishore U, Metcalfe R, Newsom-Davis J, Vincent A. Detection and characterization of MuSK antibodies in seronegative myasthenia gravis. Ann Neurol. 2004;55:580-4.

85. Ohta K, Shigemoto K, Fujinami A, Maruyama N, Konishi T, Ohta M. Clinical and experimental features of MuSK antibody positive MG in Japan. Eur J Neurol. 2007;14:1029-34.

86. Takamori M, Nakamura T, Motomura M. Antibodies against Wnt receptor of muscle-specific tyrosine kinase in myasthenia gravis. J Neuroimmunol. 2013; 254:183-6.

87. Stergiou C, Lazaridis K, Zouvelou V, Tzartos J, Mantegazza R, Antozzi C, Andreetta F, Evoli A, Deymeer F, Saruhan-Direskeneli G, et al. Titin antibodies in "seronegative" myasthenia gravis-a new role for an old antigen. J Neuroimmunol. 2016;292:108-15.

88. Gautel M, Lakey A, Barlow DP, Holmes Z, Scales S, Leonard K, Labeit S, Mygland A, Gilhus NE, Aarli JA. Titin antibodies in myasthenia gravis: identification of a major immunogenic region of titin. Neurology. 1993:43:1581-5.

89. Yamamoto AM, Gajdos P, Eymard B, Tranchant C, Warter JM, Gomez L, Bourquin C, Bach JF, Garchon HJ. Anti-titin antibodies in myasthenia gravis: tight association with thymoma and heterogeneity of nonthymoma patients. Arch Neurol. 2001;58:885-90.

90. Titulaer MJ, Wirtz PW, Kuks JB, Schelhaas HJ, van der Kooi AJ, Faber CG, van der Pol WL, de Visser M, Sillevis Smitt PA, Verschuuren JJ. The LambertEaton myasthenic syndrome 1988-2008: a clinical picture in 97 patients. J Neuroimmunol. 2008:201-202:153-8.

91. Lennon VA, Kryzer TJ, Griesmann GE, O'Suilleabhain PE, Windebank AJ, Woppmann A, Miljanich GP, Lambert EH. Calcium-channel antibodies in the Lambert-Eaton syndrome and other paraneoplastic syndromes. N Engl J Med. 1995:332:1467-74.

92. Motomura M, Johnston I, Lang B, Vincent A, Newsom-Davis J. An improved diagnostic assay for Lambert-Eaton myasthenic syndrome. J Neurol Neurosurg Psychiatry. 1995;58:85-7.
93. Takamori M, Takahashi M, Yasukawa Y, Iwasa K, Nemoto Y, Suenaga A, Nagataki S, Nakamura T. Antibodies to recombinant synaptotagmin and calcium channel subtypes in Lambert-Eaton myasthenic syndrome. J Neurol Sci. 1995;133:95-101.

94. Parsons KT, Kwok WW. Linear B-cell epitopes in Lambert-Eaton myasthenic syndrome defined by cell-free synthetic peptide binding. J Neuroimmunol. 2002;126:190-5

95. Takamori M, Iwasa K, Komai K. Antibodies to synthetic peptides of the alpha1A subunit of the voltage-gated calcium channel in Lambert-Eaton myasthenic syndrome. Neurology. 1997;48:1261-5.

96. Iwasa K, Takamori M, Komai K, Mori Y. Recombinant calcium channel is recognized by Lambert-Eaton myasthenic syndrome antibodies. Neurology. 2000;54:757-9.

97. Raymond C, Walker D, Bichet D, Iborra C, Martin-Moutot N, Seagar M, De Waard M. Antibodies against the beta subunit of voltage-dependent calcium channels in Lambert-Eaton myasthenic syndrome. Neuroscience. 1999;90:269-77.

98. Rosenfeld MR, Wong E, Dalmau J, Manley G, Posner JB, Sher E, Furneaux HM. Cloning and characterization of a Lambert-Eaton myasthenic syndrome antigen. Ann Neurol. 1993;33:113-20.

99. Verschuuren JJ, Dalmau J, Tunkel R, Lang B, Graus F, Schramm L, Posner JB, Newsom-Davis J, Rosenfeld MR. Antibodies against the calcium channel beta-subunit in Lambert-Eaton myasthenic syndrome. Neurology. 1998;50: 475-9.

100. Leveque C, Hoshino T, David P, Shoji-Kasai Y, Leys K, Omori A, Lang B, el Far O, Sato K, Martin-Moutot N, et al. The synaptic vesicle protein synaptotagmin associates with calcium channels and is a putative Lambert-Eaton myasthenic syndrome antigen. Proc Natl Acad Sci U S A. 1992;89:3625-9.

101. Shoji-Kasai Y, Yoshida A, Sato K, Hoshino T, Ogura A, Kondo S, Fujimoto Y, Kuwahara R, Kato R, Takahashi M. Neurotransmitter release from synaptotagmin-deficient clonal variants of PC12 cells. Science. 1992;256: 1821-3.

102. Shillito P, Molenaar PC, Vincent A, Leys K, Zheng W, van den Berg RJ, Plomp $J$ J, van Kempen GT, Chauplannaz G, Wintzen AR, et al. Acquired neuromyotonia: evidence for autoantibodies directed against K+ channels of peripheral nerves. Ann Neurol. 1995;38:714-22.

103. Hart IK, Waters C, Vincent A, Newland C, Beeson D, Pongs O, Morris C, Newsom-Davis J. Autoantibodies detected to expressed K+ channels are implicated in neuromyotonia. Ann Neurol. 1997;41:238-46.

104. Kleopa KA, Elman LB, Lang B, Vincent A, Scherer SS. Neuromyotonia and limbic encephalitis sera target mature Shaker-type K+ channels: subunit specificity correlates with clinical manifestations. Brain. 2006;129:1570-84.

105. Irani SR, Vincent A. Voltage-gated potassium channel-complex autoimmunity and associated clinical syndromes. Handb Clin Neurol. 2016; 133:185-97.

106. Kawamura N, Yamasaki R, Yonekawa T, Matsushita T, Kusunoki S, Nagayama S, Fukuda Y, Ogata H, Matsuse D, Murai H, Kira J. Anti-neurofascin antibody in patients with combined central and peripheral demyelination. Neurology. 2013:81:714-22.

107. Ng JK, Malotka J, Kawakami N, Derfuss T, Khademi M, Olsson T, Linington C, Odaka M, Tackenberg B, Pruss H, et al. Neurofascin as a target for autoantibodies in peripheral neuropathies. Neurology. 2012;79:2241-8.

108. Labasque M, Hivert B, Nogales-Gadea G, Querol L, Illa I, Faivre-Sarrailh C. Specific contactin $\mathrm{N}$-glycans are implicated in neurofascin binding and autoimmune targeting in peripheral neuropathies. J Biol Chem. 2014;289:7907-18.

109. van Doorn PA, Ruts $L$, Jacobs BC. Clinical features, pathogenesis, and treatment of Guillain-Barre syndrome. Lancet Neurol. 2008;7:939-50.

110. Hughes RA, Cornblath DR. Guillain-Barre syndrome. Lancet. 2005;366:1653-66.

111. Susuki K, Yuki N, Schafer DP, Hirata K, Zhang G, Funakoshi K, Rasband MN. Dysfunction of nodes of Ranvier: a mechanism for anti-ganglioside antibody-mediated neuropathies. Exp Neurol. 2012;233:534-42.

112. Yuki N, Yamada M, Koga M, Odaka M, Susuki K, Tagawa Y, Ueda S, Kasama T, Ohnishi A, Hayashi S, et al. Animal model of axonal Guillain-Barre syndrome induced by sensitization with GM1 ganglioside. Ann Neurol. 2001;49:712-20.

113. Yuki N, Yoshino H, Sato S, Miyatake T. Acute axonal polyneuropathy associated with anti-GM1 antibodies following Campylobacter enteritis. Neurology. 1990;40:1900-2.

114. Dimachkie MM, Barohn RJ. Guillain-Barre syndrome and variants. Neurol Clin. 2013;31:491-510.

115. Ang CW, Laman JD, Willison HJ, Wagner ER, Endtz HP, De Klerk MA, TioGillen AP, Van den Braak N, Jacobs BC, Van Doorn PA. Structure of 
Campylobacter jejuni lipopolysaccharides determines antiganglioside specificity and clinical features of Guillain-Barre and Miller Fisher patients. Infect Immun. 2002;70:1202-8.

116. Kaida K, Morita D, Kanzaki M, Kamakura K, Motoyoshi K, Hirakawa M, Kusunoki S. Ganglioside complexes as new target antigens in Guillain-Barre syndrome. Ann Neurol. 2004:56:567-71.

117. Notturno F, Luciani M, Caporale CM, Ciarelli A, Uncini A. Antibodies to ganglioside complexes in Guillain-Barre syndrome: clinical correlates, fine specificity and complement activation. Int I Immunopathol Pharmacol. 2009;22:437-45.

118. Sandroni P, Low PA. Other autonomic neuropathies associated with ganglionic antibody. Auton Neurosci. 2009;146:13-7.

119. Vernino S, Low PA, Fealey RD, Stewart JD, Farrugia G, Lennon VA. Autoantibodies to ganglionic acetylcholine receptors in autoimmune autonomic neuropathies. N Engl J Med. 2000;343:847-55.

120. McKeon A, Lennon VA, Lachance DH, Fealey RD, Pittock SJ. Ganglionic acetylcholine receptor autoantibody: oncological, neurological, and serological accompaniments. Arch Neurol. 2009;66:735-41.

121. Vernino S, Lindstrom J, Hopkins S, Wang Z, Low PA, Muscle SG. Characterization of ganglionic acetylcholine receptor autoantibodies. J Neuroimmunol. 2008:197:63-9.

122. Nakane S, Higuchi O, Hamada Y, Maeda Y, Mukaino A, Sakai W, Kusunoki S, Matsuo H. Ganglionic acetylcholine receptor autoantibodies in patients with Guillain-Barre syndrome. J Neuroimmunol. 2016;295-296:54-9.

123. Lennon VA, Ermilov LG, Szurszewski JH, Vernino S. Immunization with neuronal nicotinic acetylcholine receptor induces neurological autoimmune disease. J Clin Invest. 2003;111:907-13.

124. Vernino S, Low PA, Lennon VA. Experimental autoimmune autonomic neuropathy. J Neurophysiol. 2003;90:2053-9.

125. Palanichamy A, Apeltsin L, Kuo TC, Sirota M, Wang S, Pitts SJ, Sundar PD Telman D, Zhao LZ, Derstine M, et al. Immunoglobulin class-switched B cells form an active immune axis between CNS and periphery in multiple sclerosis. Sci Transl Med. 2014;6:248ra106.

126. Stern JN, Yaari G, Vander Heiden JA, Church G, Donahue WF, Hintzen RQ, Huttner AJ, Laman JD, Nagra RM, Nylander A, et al. B cells populating the multiple sclerosis brain mature in the draining cervical lymph nodes. Sci Transl Med. 2014;6:248ra107.

127. Apiwattanakul M, Asawavichienjinda T, Pulkes T, Tantirittisak T, Hemachudha T, Horta ES, Jenkins SM, Pittock SJ. Diagnostic utility of NMO/AQP4-IgG in evaluating CNS inflammatory disease in Thai patients. J Neurol Sci. 2012;320:118-20.

128. Jarius S, Frederikson J, Waters P, Paul F, Akman-Demir G, Marignier R, Franciotta D, Ruprecht K, Kuenz B, Rommer P, et al. Frequency and prognostic impact of antibodies to aquaporin-4 in patients with optic neuritis. J Neurol Sci. 2010;298:158-62.

129. Waters PJ, McKeon A, Leite MI, Rajasekharan S, Lennon VA, Villalobos A, Palace J, Mandrekar JN, Vincent A, Bar-Or A, Pittock SJ. Serologic diagnosis of NMO: a multicenter comparison of aquaporin-4-IgG assays. Neurology. 2012;78:665-71. discussion 669.

130. Marignier R, Bernard-Valnet R, Giraudon P, Collongues N, Papeix C, Zephir $H$, Cavillon G, Rogemond V, Casey R, Frangoulis B, et al. Aquaporin-4 antibodynegative neuromyelitis optica: distinct assay sensitivity-dependent entity. Neurology. 2013;80:2194-200

131. Fryer JP, Lennon VA, Pittock SJ, Jenkins SM, Fallier-Becker P, Clardy SL, Horta E, Jedynak EA, Lucchinetti CF, Shuster EA, et al. AQP4 autoantibody assay performance in clinical laboratory service. Neurol Neuroimmunol Neuroinflamm. 2014;1:e11.

132. Jarius S, Paul F, Fechner K, Ruprecht K, Kleiter I, Franciotta D, Ringelstein M, Pache F, Aktas O, Wildemann B. Aquaporin-4 antibody testing: direct comparison of M1-AQP4-DNA-transfected cells with leaky scanning versus M23-AQP4-DNA-transfected cells as antigenic substrate. J Neuroinflammation. 2014:11:129.

133. Waters P, Reindl M, Saiz A, Schanda K, Tuller F, Kral V, Nytrova P, Sobek O, Nielsen $\mathrm{HH}$, Barington $\mathrm{T}$, et al. Multicentre comparison of a diagnostic assay: aquaporin-4 antibodies in neuromyelitis optica. J Neurol Neurosurg Psychiatry. 2016

134. Bennett JL, Lam C, Kalluri SR, Saikali P, Bautista K, Dupree C, Glogowska M, Case D, Antel JP, Owens GP, et al. Intrathecal pathogenic anti-aquaporin-4 antibodies in early neuromyelitis optica. Ann Neurol. 2009;66:617-29.

135. Dalmau J, Gleichman AJ, Hughes EG, Rossi JE, Peng X, Lai M, Dessain SK, Rosenfeld MR, Balice-Gordon R, Lynch DR. Anti-NMDA-receptor encephalitis: case series and analysis of the effects of antibodies. Lancet Neurol. 2008;7:1091-8.

136. Hughes EG, Peng X, Gleichman AJ, Lai M, Zhou L, Tsou R, Parsons TD, Lynch DR, Dalmau J, Balice-Gordon RJ. Cellular and synaptic mechanisms of antiNMDA receptor encephalitis. J Neurosci. 2010;30:5866-75.

137. Mikasova L, De Rossi P, Bouchet D, Georges F, Rogemond V, Didelot A, Meissirel C, Honnorat J, Groc L. Disrupted surface cross-talk between NMDA and Ephrin-B2 receptors in anti-NMDA encephalitis. Brain. 2012;135:1606-21.

138. Planaguma J, Leypoldt F, Mannara F, Gutierrez-Cuesta J, Martin-Garcia E, Aguilar E, Titulaer MJ, Petit-Pedrol M, Jain A, Balice-Gordon R, et al. Human $\mathrm{N}$-methyl $\mathrm{D}$-aspartate receptor antibodies alter memory and behaviour in mice. Brain. 2015;138:94-109.

139. Wright S, Hashemi K, Stasiak L, Bartram J, Lang B, Vincent A, Upton AL. Epileptogenic effects of NMDAR antibodies in a passive transfer mouse model. Brain. 2015;138:3159-67.

140. Manto MU, Hampe CS, Rogemond V, Honnorat J. Respective implications of glutamate decarboxylase antibodies in stiff person syndrome and cerebellar ataxia. Orphanet J Rare Dis. 2011;6:3.

141. Manto MU, Laute MA, Aguera M, Rogemond V, Pandolfo M, Honnorat J. Effects of anti-glutamic acid decarboxylase antibodies associated with neurological diseases. Ann Neurol. 2007;61:544-51.

142. Hampe CS, Petrosini L, De Bartolo P, Caporali P, Cutuli D, Laricchiuta D, Foti F, Radtke JR, Vidova V, Honnorat J, Manto M. Monoclonal antibodies to $65 \mathrm{kDa}$ glutamate decarboxylase induce epitope specific effects on motor and cognitive functions in rats. Orphanet J Rare Dis. 2013;8:82.

143. Hill KE, Clawson SA, Rose JW, Carlson NG, Greenlee JE. Cerebellar Purkinje cells incorporate immunoglobulins and immunotoxins in vitro: implications for human neurological disease and immunotherapeutics. J Neuroinflammation. 2009;6:31.

144. Kortvelyessy P, Bauer J, Stoppel CM, Bruck W, Gerth I, Vielhaber S, Wiedemann FR, Heinze HJ, Bartels C, Bien CG. Complement-associated neuronal loss in a patient with CASPR2 antibody-associated encephalitis. Neurol Neuroimmunol Neuroinflamm. 2015;2:e75.

145. Kerlero De Rosbo N, Honegger P, Lassmann H, Matthieu JM. Demyelination induced in aggregating brain cell cultures by a monoclonal antibody against myelin/oligodendrocyte glycoprotein. J Neurochem. 1990;55:583-7.

146. Piddlesden SJ, Lassmann H, Zimprich F, Morgan BP, Linington C. The demyelinating potential of antibodies to myelin oligodendrocyte glycoprotein is related to their ability to fix complement. Am J Pathol. 1993; 143:555-64.

147. Dale RC, Tantsis EM, Merheb V, Kumaran RA, Sinmaz N, Pathmanandavel K, Ramanathan S, Booth DR, Wienholt LA, Prelog K, et al. Antibodies to MOG have a demyelination phenotype and affect oligodendrocyte cytoskeleton Neurol Neuroimmunol Neuroinflammation. 2014;1:1-10.

148. Tzartos $S$, Hochschwender S, Vasquez P, Lindstrom J. Passive transfer of experimental autoimmune myasthenia gravis by monoclonal antibodies to the main immunogenic region of the acetylcholine receptor. J Neuroimmunol. 1987;15:185-94.

149. Zhang W, Coldefy AS, Hubbard SR, Burden SJ. Agrin binds to the N-terminal region of Lrp4 protein and stimulates association between Lrp4 and the first immunoglobulin-like domain in muscle-specific kinase (MuSK). J Biol Chem. 2011;286:40624-30.

150. Mossman S, Vincent A, Newsom-Davis J. Myasthenia gravis without acetylcholine-receptor antibody: a distinct disease entity. Lancet. 1986;1:116-9.

151. Cole RN, Reddel SW, Gervasio OL, Phillips WD. Anti-MuSK patient antibodies disrupt the mouse neuromuscular junction. Ann Neurol. 2008;63:782-9.

152. Shen C, Lu Y, Zhang B, Figueiredo D, Bean J, Jung J, Wu H, Barik A, Yin DM, Xiong WC, Mei L. Antibodies against low-density lipoprotein receptorrelated protein 4 induce myasthenia gravis. J Clin Invest. 2013;123:5190-202.

153. Takamori M, Hamada T, Komai K, Takahashi M, Yoshida A. Synaptotagmin can cause an immune-mediated model of Lambert-Eaton myasthenic syndrome in rats. Ann Neurol. 1994;35:74-80.

154. Bloom O, Cheng KF, He M, Papatheodorou A, Volpe BT, Diamond B, Al-Abed Y. Generation of a unique small molecule peptidomimetic that neutralizes lupus autoantibody activity. Proc Natl Acad Sci U S A. 2011; 108:10255-9.

155. Diamond B, Bloom O, Al Abed Y, Kowal C, Huerta PT, Volpe BT. Moving towards a cure: blocking pathogenic antibodies in systemic lupus erythematosus. J Intern Med. 2011;269:36-44.

156. Luo J, Lindstrom J. Antigen-specific immunotherapeutic vaccine for experimental autoimmune myasthenia gravis. J Immunol. 2014;193:5044-55. 
157. Papadopoulos MC, Bennett JL, Verkman AS. Treatment of neuromyelitis optica: state-of-the-art and emerging therapies. Nat Rev Neurol. 2014;10: 493-506.

158. Tradtrantip L, Zhang H, Saadoun S, Phuan PW, Lam C, Papadopoulos MC, Bennett JL, Verkman AS. Anti-aquaporin-4 monoclonal antibody blocker therapy for neuromyelitis optica. Ann Neurol. 2012;71:314-22.

159. Titulaer MJ, Kayser MS, Dalmau J. Prevalence and treatment of anti-NMDA receptor encephalitis. Lancet Neurol. 2013;12:425-6.

160. Fujinami RS, Oldstone MB, Wroblewska Z, Frankel ME, Koprowski H. Molecular mimicry in virus infection: crossreaction of measles virus phosphoprotein or of herpes simplex virus protein with human intermediate filaments. Proc Natl Acad Sci U S A. 1983;80:2346-50.

161. Oldstone MB. Molecular mimicry and immune-mediated diseases. FASEB J. 1998;12:1255-65.

162. Kampylafka El, Alexopoulos H, El Hamidieh A, Dalakas MC, Andreakos E, Tzioufas AG. Immunization of mice with a peptide derived from the HTLV-1 TAX1BP1 protein induces cross-reactive antibodies against aquaporin 4. Autoimmunity. 2015;48:1-7.

163. Desena A, Graves D, Warnack W, Greenberg BM. Herpes simplex encephalitis as a potential cause of anti-N-methyl-D-aspartate receptor antibody encephalitis: report of 2 cases. JAMA Neurol. 2014;71:344-6.

164. Hacohen $Y$, Deiva K, Pettingill $P$, Waters $P$, Siddiqui $A$, Chretien $P$, Menson $E$, Lin JP, Tardieu M, Vincent A, Lim MJ. N-methyl-D-aspartate receptor antibodies in post-herpes simplex virus encephalitis neurological relapse. Mov Disord. 2014;29:90-6.

165. Mohammad SS, Sinclair K, Pillai S, Merheb V, Aumann TD, Gill D, Dale RC, Brilot F. Herpes simplex encephalitis relapse with chorea is associated with autoantibodies to N-Methyl-D-aspartate receptor or dopamine-2 receptor. Mov Disord. 2014;29:117-22.

166. Titulaer MJ, Leypoldt F, Dalmau J. Antibodies to N-methyl-D-aspartate and other synaptic receptors in choreoathetosis and relapsing symptoms postherpes virus encephalitis. Mov Disord. 2014;29:3-6.

167. Armangue T, Leypoldt F, Malaga I, Raspall-Chaure M, Marti I, Nichter C, Pugh J, Vicente-Rasoamalala M, Lafuente-Hidalgo M, Macaya A, et al. Herpes simplex virus encephalitis is a trigger of brain autoimmunity. Ann Neurol. 2014:75:317-23.

168. Schabitz WR, Rogalewski A, Hagemeister C, Bien CG. VZV brainstem encephalitis triggers NMDA receptor immunoreaction. Neurology. 2014;83: 2309-11.

169. Cox CJ, Sharma M, Leckman JF, Zuccolo J, Zuccolo A, Kovoor A, Swedo SE, Cunningham MW. Brain human monoclonal autoantibody from sydenham chorea targets dopaminergic neurons in transgenic mice and signals dopamine D2 receptor: implications in human disease. J Immunol. 2013;191:5524-41.

170. Rees JH, Soudain SE, Gregson NA, Hughes RA. Campylobacter jejuni infection and Guillain-Barre syndrome. N Engl J Med. 1995;333:1374-9.

171. Moran AP, Annuk H, Prendergast MM. Antibodies induced by gangliosidemimicking Campylobacter jejuni lipooligosaccharides recognise epitopes at the nodes of Ranvier. J Neuroimmunol. 2005;165:179-85.

172. Godschalk PC, Heikema AP, Gilbert M, Komagamine T, Ang CW, Glerum J, Brochu D, Li J, Yuki N, Jacobs BC, et al. The crucial role of Campylobacter jejuni genes in anti-ganglioside antibody induction in Guillain-Barre syndrome. J Clin Invest. 2004;114:1659-65.

173. Nachamkin I, Liu J, Li M, Ung H, Moran AP, Prendergast MM, Sheikh K. Campylobacter jejuni from patients with Guillain-Barre syndrome preferentially expresses a GD(1a)-like epitope. Infect Immun. 2002;70:5299-303.

174. Holland M, Yagi H, Takahashi N, Kato K, Savage CO, Goodall DM, Jefferis R. Differential glycosylation of polyclonal lgG, IgG-FC and lgG-Fab isolated from the sera of patients with ANCA-associated systemic vasculitis. Biochim Biophys Acta. 2006;1760:669-77.

175. Parekh R, Isenberg D, Rook G, Roitt I, Dwek R, Rademacher T. A comparative analysis of disease-associated changes in the galactosylation of serum lgG. J Autoimmun. 1989:2:101-14.

176. Parekh RB, Dwek RA, Sutton BJ, Fernandes DL, Leung A, Stanworth D, Rademacher TW, Mizuochi T, Taniguchi T, Matsuta K, et al. Association of rheumatoid arthritis and primary osteoarthritis with changes in the glycosylation pattern of total serum IgG. Nature. 1985;316:452-7.

177. Selman MH, de Jong SE, Soonawala D, Kroon FP, Adegnika AA, Deelder AM, Hokke CH, Yazdanbakhsh M, Wuhrer M. Changes in antigen-specific lgG1 FC $\mathrm{N}$-glycosylation upon influenza and tetanus vaccination. Mol Cell Proteomics. 2012;11:M111 014563.
178. Selman MH, Niks EH, Titulaer MJ, Verschuuren JJ, Wuhrer M, Deelder AM. IgG fc N-glycosylation changes in Lambert-Eaton myasthenic syndrome and myasthenia gravis. J Proteome Res. 2011;10:143-52.

179. Maverakis E, Kim K, Shimoda M, Gershwin ME, Patel F, Wilken R, Raychaudhuri S, Ruhaak LR, Lebrilla CB. Glycans in the immune system and The Altered Glycan Theory of Autoimmunity: a critical review. J Autoimmun. 2015;57:1-13

180. Pittock SJ, Kryzer TJ, Lennon VA. Paraneoplastic antibodies coexist and predict cancer, not neurological syndrome. Ann Neurol. 2004;56:715-9.

181. Pellkofer HL, Kuempfel T, Jacobson L, Vincent A, Derfuss T. Nonparaneoplastic limbic encephalitis associated with NMDAR and VGKC antibodies. J Neurol Neurosurg Psychiatry. 2010;81:1407-8.

182. Boronat A, Sabater L, Saiz A, Dalmau J, Graus F. GABA(B) receptor antibodies in limbic encephalitis and anti-GAD-associated neurologic disorders. Neurology. 2011;76:795-800

183. Dogan Onugoren M, Deuretzbacher D, Haensch CA, Hagedorn HJ, Halve S, Isenmann S, Kramme C, Lohner H, Melzer N, Monotti R, et al. Limbic encephalitis due to GABAB and AMPA receptor antibodies: a case series. J Neurol Neurosurg Psychiatry. 2015;86:965-72.

184. Gagnon MM, Savard M, Mourabit AK. Refractory status epilepticus and autoimmune encephalitis with GABAR and GAD65 antibodies: a case report. Seizure. 2016:37:25-7.

185. Cistaro A, Caobelli F, Quartuccio N, Fania P, Pagani M. Uncommon 18F-FDG$\mathrm{PET} / \mathrm{CT}$ findings in patients affected by limbic encephalitis: hyperhypometabolic pattern with double antibody positivity and migrating foci of hypermetabolism. Clin Imaging. 2015;39:329-33.

186. Pathmanandavel K, Starling J, Merheb V, Ramanathan S, Sinmaz N, Dale RC, Brilot F. Antibodies to surface dopamine-2 receptor and N-methyl-daspartate receptor in the first episode of acute psychosis in children. Biol Psychiatry. 2015;77:537-47.

187. Guan HZ, Ren HT, Yang XZ, Lu Q, Peng B, Zhu YC, Shao XQ, Hu YQ, Zhou D, Cui LY. Limbic encephalitis associated with anti-gamma-aminobutyric acid $B$ receptor antibodies: a case series from China. Chin Med J (Engl). 2015;128:3023-8.

188. Zhang L, Lu Q, Guan HZ, Mei JH, Ren HT, Liu MS, Peng B, Cui LY. A Chinese female Morvan patient with LGI1 and CASPR2 antibodies: a case report. BMC Neurol. 2016;16:37.

189. Titulaer MJ, Hoftberger R, lizuka T, Leypoldt F, McCracken L, Cellucci T, Benson LA, Shu H, Irioka T, Hirano M, et al. Overlapping demyelinating syndromes and anti-N-methyl-D-aspartate receptor encephalitis. Ann Neurol. 2014;75:411-28.

190. Hacohen Y, Nishimoto Y, Fukami Y, Lang B, Waters P, Lim MJ, Yuki N, Vincent A. Paediatric brainstem encephalitis associated with glial and neuronal autoantibodies. Dev Med Child Neurol. 2016.

191. Oh SJ. Myasthenia gravis Lambert-Eaton overlap syndrome. Muscle Nerve. 2016:53:20-6.

192. Katz JS, Wolfe Gl, Bryan WW, Tintner R, Barohn RJ. Acetylcholine receptor antibodies in the Lambert-Eaton myasthenic syndrome. Neurology. 1998; $50: 470-5$

193. Newsom-Davis J, Leys K, Vincent A, Ferguson I, Modi G, Mills K. Immunological evidence for the co-existence of the Lambert-Eaton myasthenic syndrome and myasthenia gravis in two patients. J Neurol Neurosurg Psychiatry. 1991;54:452-3.

194. Oh SJ, Sher E. MG and LEMS overlap syndrome: case report with electrophysiological and immunological evidence. Clin Neurophysiol. 2005;116:1167-71

195. Diaz-Manera J, Rojas-Garcia R, Gallardo E, Juarez C, Martinez-Domeno A, Martinez-Ramirez S, Dalmau J, Blesa R, Illa I. Antibodies to AChR, MuSK and VGKC in a patient with myasthenia gravis and Morvan's syndrome. Nat Clin Pract Neurol. 2007:3:405-10.

196. Lauvsnes MB, Omdal R. Systemic lupus erythematosus, the brain, and antiNR2 antibodies. J Neurol. 2012;259:622-9.

197. Dogan Onugoren M, Rauschka H, Bien CG. Conjoint occurrence of GABAB receptor antibodies in Lambert-Eaton myasthenic syndrome with antibodies to the voltage gated calcium channel. J Neuroimmunol. 2014;273:115-6.

198. Ogawara K, Kuwabara S, Koga M, Mori M, Yuki N, Hattori T. Anti-GM1b lgG antibody is associated with acute motor axonal neuropathy and Campylobacter jejuni infection. J Neurol Sci. 2003;210:41-5.

199. Krampfl K, Mohammadi B, Buchwald B, Jahn K, Dengler R, Toyka KV, Bufler J. IgG from patients with Guillain-Barre syndrome interact with nicotinic acetylcholine receptor channels. Muscle Nerve. 2003;27:435-41. 
200. Tuzun E, Kurtuncu M, Lang B, Icoz S, Akman-Demir G, Eraksoy M, Vincent A. Bickerstaff's encephalitis and Miller Fisher syndrome associated with voltage-gated potassium channel and novel anti-neuronal antibodies. Eur J Neurol. 2010;17:1304-7.

201. Leite Ml, Coutinho E, Lana-Peixoto M, Apostolos S, Waters P, Sato D, Melamud L, Marta M, Graham A, Spillane J, et al. Myasthenia gravis and neuromyelitis optica spectrum disorder: a multicenter study of 16 patients. Neurology. 2012;78:1601-7.

202. Tuohy VK, Kinkel RP. Epitope spreading: a mechanism for progression of autoimmune disease. Arch Immunol Ther Exp (Warsz). 2000;48:347-51.

203. Feferman T, Im SH, Fuchs S, Souroujon MC. Breakage of tolerance to hidden cytoplasmic epitopes of the acetylcholine receptor in experimental autoimmune myasthenia gravis. J Neuroimmunol. 2003;140:153-8.

204. McMahon EJ, Bailey SL, Castenada CV, Waldner H, Miller SD. Epitope spreading initiates in the CNS in two mouse models of multiple sclerosis. Nat Med. 2005;11:335-9.

205. McCarron RM, Fallis RJ, McFarlin DE. Alterations in T cell antigen specificity and class $\|$ restriction during the course of chronic relapsing experimental allergic encephalomyelitis. J Neuroimmunol. 1990;29:73-9.

206. Lehmann PV, Forsthuber T, Miller A, Sercarz EE. Spreading of T-cell autoimmunity to cryptic determinants of an autoantigen. Nature. 1992;358:155-7.

207. Bhardwaj V, Kumar V, Grewal IS, Dao T, Lehmann PV, Geysen HM, Sercarz EE. T cell determinant structure of myelin basic protein in B10.PL, SJL/J, and their F1S. J Immunol. 1994;152:3711-9.

208. Mor F, Cohen IR. Shifts in the epitopes of myelin basic protein recognized by Lewis rat T cells before, during, and after the induction of experimental autoimmune encephalomyelitis. J Clin Invest. 1993;92:2199-206.

209. Quintana FJ, Patel B, Yeste A, Nyirenda M, Kenison J, Rahbari R, Fetco D, Hussain M, O'Mahony J, Magalhaes S, et al. Epitope spreading as an early pathogenic event in pediatric multiple sclerosis. Neurology. 2014;83:2219-26.

210. Varrin-Doyer M, Spencer CM, Schulze-Topphoff U, Nelson PA, Stroud RM, Cree BA, Zamvil SS. Aquaporin 4-specific T cells in neuromyelitis optica exhibit a Th17 bias and recognize Clostridium ABC transporter. Ann Neurol, 2012;72:53-64

211. Verkman AS, Ratelade J, Rossi A, Zhang H, Tradtrantip L. Aquaporin-4: orthogonal array assembly, CNS functions, and role in neuromyelitis optica. Acta Pharmacol Sin. 2011;32:702-10.

\section{Submit your next manuscript to BioMed Central and we will help you at every step:}

- We accept pre-submission inquiries

- Our selector tool helps you to find the most relevant journal

- We provide round the clock customer support

- Convenient online submission

- Thorough peer review

- Inclusion in PubMed and all major indexing services

- Maximum visibility for your research

Submit your manuscript at www.biomedcentral.com/submit

) Biomed Central 